\title{
Coccolithophore productivity at the western Iberian Margin during the Middle Pleistocene (310-455 ka) - evidence from coccolith Sr/Ca data
}

\author{
Catarina Cavaleiro $^{1,2,3}$, Antje H. L. Voelker ${ }^{2,3}$, Heather Stoll ${ }^{4, a}$, Karl-Heinz Baumann ${ }^{5}$, and Michal Kucera ${ }^{1}$ \\ ${ }^{1}$ University of Bremen, MARUM - Center for Marine and Environmental Sciences, Leobener Straße 8, \\ 28359 Bremen, Germany \\ ${ }^{2}$ IPMA - Instituto Português do Mar e da Atmosfera, Divisão de Geologia Marinha e Georecursos Marinhos, \\ Avenida Doutor Alfredo Magalhães Ramalho 6, 1495-165 Algés, Portugal \\ ${ }^{3}$ CCMAR, Centro de Ciências do Mar, Universidade do Algarve, Campus de Gambelas, 8005-139 Faro, Portugal \\ ${ }^{4}$ Geology Department, University of Oviedo, C/. Jesús Arias de Velasco s/n, 33005, Oviedo, Spain \\ ${ }^{5}$ University of Bremen, Geosciences Department, Klagenfurter Straße 2-4, 28359 Bremen, Germany \\ anow at: Department of Earth Sciences, ETH Zürich, Sonneggstrasse 5, 8092 Zürich, Switzerland
}

Correspondence: Catarina Cavaleiro (cdcavaleiro@gmail.com)

Received: 21 October 2019 - Discussion started: 29 October 2019

Revised: 14 August 2020 - Accepted: 18 September 2020 - Published: 3 November 2020

\begin{abstract}
Coccolithophores contribute significantly to marine primary productivity and play a unique role in ocean biogeochemistry by using carbon for photosynthesis (soft-tissue pump) and for calcification (carbonate counter pump). Despite the importance of including coccolithophores in Earth system models to allow better predictions of the climate system's responses to planetary change, the reconstruction of coccolithophore productivity mostly relied on proxies dependent on accumulation and sedimentation rates and preservation conditions. In this study we used an independent proxy, based on the coccolith fraction (CF) $\mathrm{Sr} / \mathrm{Ca}$ ratio, to reconstruct coccolithophore productivity. We studied the marine sediment core MD03-2699 from the western Iberian margin (IbM), concentrating on glacial-interglacial cycles of Marine Isotopic Stage (MIS) 12 to MIS 9. We found that IbM coccolithophore productivity was controlled by changes in the oceanographic conditions, such as in sea surface temperature (SST) and nutrient availability, and by competition with other phytoplankton groups. Long-term coccolithophore productivity was primarily affected by variations in the dominant surface water mass. Polar and subpolar surface waters during glacial substages were associated with decreased coccolithophore productivity, with the strongest productivity minima concomitant with Heinrich-type events (HtEs).
\end{abstract}

Subtropical, nutrient-poorer waters, increased terrigenous input, and moderate to strong upwelling during the deglaciation and early MIS11 are hypothesized to have attributed a competitive advantage to diatoms to the detriment of coccolithophores, resulting in intermediate coccolithophore productivity levels. During the progression towards full glacial conditions an increasing presence of nutrient-richer waters, related to the growing influence of transitional surface waters and/or intensified upwelling, probably stimulated coccolithophore productivity to maxima following the rapid depletion of silica by diatoms. We present conceptual models of the carbon and carbonate cycle components for the IbM in different time slices that might serve as a basis for further investigation and modelling experiments.

\section{Introduction}

Coccolithophores play a unique role in ocean biogeochemistry using carbon for both photosynthesis and calcification (e.g. Rost and Riebesell, 2004; Westbroek et al., 1993) and contributing up to $60 \%$ to the total calcium carbonate in the ocean (Flores and Sierro, 2007). During the mid-Brunhes interval of Marine Isotope Stage (MIS) 14 to MIS 9, when the assemblages were vastly dominated by gephyrocapsids 
(Baumann and Freitag, 2004; Saavedra-Pellitero et al., 2017), coccolithophores provided $>80 \%$ of the total oceanic calcium carbonate. And, several studies hypothesized a relevant role of coccolithophores in glacial-interglacial dynamics (Duchamp-Alphonse et al., 2018; McClelland et al., 2016; Omta et al., 2013; Rickaby et al., 2007; Saavedra-Pellitero et al., 2017), but there are uncertainties arising from the complex interactions between coccolithophore productivity and growth rates, nutrient dynamics and competition with non-calcifiers, seasonality and the export of both carbonate and organic carbon, and the final accumulation/burial rates (Balch, 2018; Duchamp-Alphonse et al., 2018; McClelland et al., 2016; Omta et al., 2013; Rickaby et al., 2007; Ridgwell and Zeebe, 2005; Saavedra-Pellitero et al., 2017). These uncertainties make the inclusion of biogeochemical processes related to coccolithophores in Earth system models challenging. In order to provide useful information to modellers, it is thus fundamental to test the dynamic response of the various components of the system over different climatic scenarios through the use of multiproxy studies involving the reconstruction of coccolithophore growth rates and the export of both their organic and inorganic compounds, namely alkenones and nannofossil accumulation rate (AlkAR and NAR, respectively).

Since coccolithophores are sensitive to rapid fluctuations in temperature, salinity, nutrients, and turbidity of surface waters (Baumann et al., 2005; McIntyre and Bé, 1967), their calcareous remains, the coccoliths, retrieved from deep-sea sediments have been used extensively to reconstruct paleoenvironmental conditions (Amore et al., 2012; Baumann et al., 2005; Beaufort et al., 2001; Flores et al., 1997; Maiorano et al., 2015; Marino et al., 2014; McIntyre and Molfino, 1996; Saavedra-Pellitero et al., 2017). However, coccolithophore paleoproductivity reconstruction has been tentative and mostly relied on proxies dependent not only on the extent of the supply but also on dilution by mineral matter, changes in sedimentation or accumulation rates, and preservation conditions (Rullkötter, 2006). Beaufort et al. (1997) proposed a proxy to quantitatively reconstruct coccolithophore productivity, but its applicability is unfortunately limited to latitudes between $30^{\circ} \mathrm{N}$ and $30^{\circ} \mathrm{S}$ (Hernández-Almeida et al., 2019). A widely used alternative proxy is the coccolith fraction $\mathrm{Sr} / \mathrm{Ca}(\mathrm{CF} \mathrm{Sr} / \mathrm{Ca})$ ratio that is independent of accumulation rate (Cavaleiro et al., 2018; Mejía et al., 2014; Saavedra-Pellitero et al., 2017; Tangunan et al., 2017). Coccolithophores construct coccoliths internally within their cell and several studies show the direct and proportional relationship between the $\mathrm{Sr} / \mathrm{Ca}$ ratio of the coccolith and the coccolith calcification rate. The calcification rate is a function of growth rate (e.g. Daniels et al., 2018) and therefore of coccolithophore productivity (Balch et al., 1996; Rickaby et al., 2007; Stoll and Schrag, 2000). The faster coccolithophores grow, the faster they calcify and more $\mathrm{Sr}$ is incorporated into the calcite lattice of their coccoliths (Stoll et al., 2002b, a; Stoll and Schrag, 2000). With temperature and assemblage effects considered (see "Material and methods" section), the sea surface temperature (SST)-corrected CF Sr/Ca curve (or residual curve) can be expected to reflect coccolithophores' growth rate and thus their productivity qualitatively (Müller et al., 2014; Stoll et al., 2002a).

Coccolithophores research has been gaining increased attention because of their potential relevant role in the carbon cycle (Ridgwell and Zeebe, 2005). The carbon cycle underwent major changes during the past $800 \mathrm{kyr}$ as evidenced, for example, by the glacial-interglacial variations in atmospheric carbon dioxide $\left(\mathrm{atmCO}_{2}\right)$ concentrations (Lüthi et al., 2008). Though the changing orbital parameters of Earth (i.e. the Milankovitch cycles) are undoubtedly related to the glacial-interglacial cycles (e.g. Berger, 1988), the mechanisms driving the almost $80 \mathrm{ppmv}$ lower atmCO $\mathrm{CO}_{2}$ concentrations during glacial periods and the rapid rise during deglaciations are yet to be described and modelled accurately (Barker et al., 2006; Duchamp-Alphonse et al., 2018; Omta et al., 2013; Ridgwell and Zeebe, 2005). Since the ocean contains 60 times more carbon than the atmosphere, modest changes in its holding capacity could greatly affect atmCO ${ }_{2}$ (e.g. Sarmiento and Gruber, 2007). It is clear that atmCO ${ }_{2}$ changes are a consequence of the interplay of several factors and not a single mechanism at work (Archer et al., 2000; Sigman and Boyle, 2000). Yet, theories such as the "coral reef hypothesis" (Berger, 1982), "carbonate compensation" (Broecker and Peng, 1987), and "rain ratio hypothesis" (Archer and Maier-Reimer, 1994) give the marine carbonate cycle a determinant role in atmCO ${ }_{2}$ changes on timescales shorter than $100 \mathrm{kyr}$ (e.g. Ridgwell and Zeebe, 2005, Broecker, 1982).

Our studied period falls into the mid-Brunhes interval (Barker et al., 2006; Baumann and Freitag, 2004; Jansen et al., 1986) when, starting with MIS 11c, interglacial atmCO2 levels were comparable to the Holocene (Lüthi et al., 2008). The mid-Brunhes interval also has the advantage to cover the Gephyrocapsa caribbeanica acme (Baumann and Freitag, 2004), reducing the likelihood of a biasing effect of the $\mathrm{CF} \mathrm{Sr} / \mathrm{Ca}$ ratio from changing coccolith assemblages (see "Material and methods" section). It encompasses different climatic scenarios, from late MIS 12 to early MIS 9, straddling the harsh glacial of MIS 12 and the prolonged MIS 11c interglacial period, considered to be one of the best analogues for the current MIS 1 interglacial (Berger et al., 2015; Candy et al., 2014; Loutre and Berger, 2003; Oliveira et al., 2018). The deglaciation and termination $(\mathrm{T}) \mathrm{V}$ is considered one of the longest deglaciations (Tzedakis et al., 2012; Vázquez Riveiros et al., 2013), and the highest glacial-interglacial amplitude change of the last $1 \mathrm{Myr}$ (Lisiecki and Raymo, 2005) allowing a more detailed analysis due to the high sedimentation rates that characterize the western Iberian Margin (IbM).

The western IbM embodies the northern section of the Canary Current Eastern Boundary Upwelling System (Arístegui et al., 2009; Mason et al., 2006). The seasonal meridional shifts in the atmospheric highs revert the upwelling favour- 
ing equatorward winds seasonally to become poleward in autumn and winter (Mason et al., 2006). Despite representing only $10 \%$ of the ocean, the Eastern Boundary Upwelling Systems contribute $80 \%$ to $90 \%$ to the oceanic new production (Hill et al., 1998, Ryther, 1969). These systems are sensitive to climate change by responding to shifts in processes that regulate ocean stratification, upwelling, wind stress, dust supply, and basin-wide circulation (Freon et al., 2009). However, to infer the role of climate modes in modulating air-sea $\mathrm{CO}_{2}$ fluxes in such a complex environment is challenging although this knowledge is crucial to improve our ability to predict future evolution of atmCO $\mathrm{CO}_{2}$ (Brady et al., 2019).

In this study we reconstruct coccolithophore productivity from the CF Sr/Ca ratio record at Site MD03-2699, an area under the influence of the Canary Current upwelling system, and particularly sensitive to global climate change (Hodell et al., 2015; Martrat et al., 2007; Oliveira et al., 2016; Rodrigues et al., 2017) and thus optimal to evaluate this phytoplankton group's behaviour to varying conditions. Using a multiproxy approach, we compare the $\mathrm{CF} \mathrm{Sr} / \mathrm{Ca}$ data with the total alkenone concentration (i.e. the exported organic carbon produced by coccolithophores), as well as with the NARs in order to investigate the processes of production versus export and preservation of both organic and inorganic carbon. This approach allows us to gain a better understanding of (1) the coupling-decoupling between the different proxies used to reconstruct coccolithophores' productivity and (2) the role of upwelling strength and terrigenous input in nutrient competition under different climate conditions, such as glacials, interglacials, deglaciations, and the transition from interglacial to glacial conditions.

\section{Regional setting}

\subsection{Present hydrography of the IbM}

The study area is located at the north-eastern edge of the subtropical gyre and influenced by a southward flowing branch of the North Atlantic Current forming the Portugal Current system (Fig. 1). The Portugal Current system is mainly characterized by a slow, southerly flow with intricate interaction between coastal and offshore currents (Peliz et al., 2005; Relvas et al., 2007), bottom topography, and water mass convergence (Bischof et al., 2003). One of the most important features of the IbM is the surface circulation's seasonality as a response to the combined position of the Azores High and the Icelandic low-pressure systems (Barton, 2001; Haynes and Barton, 2018; Relvas et al., 2007). During summer, the migration of the Azores High to the central Atlantic exposes the IbM to northerly trade winds, strengthening the Portugal Current and forcing the upper layer (150 to $200 \mathrm{~m}$ ) to flow towards the Equator. The induced offshore Ekman transport allows colder, less salty, and nutrient-rich subsurface water to rise to the surface (Alvarez et al., 2011; Fiúza, 1983), which leads to high primary production (Figueiras et al., 2002;

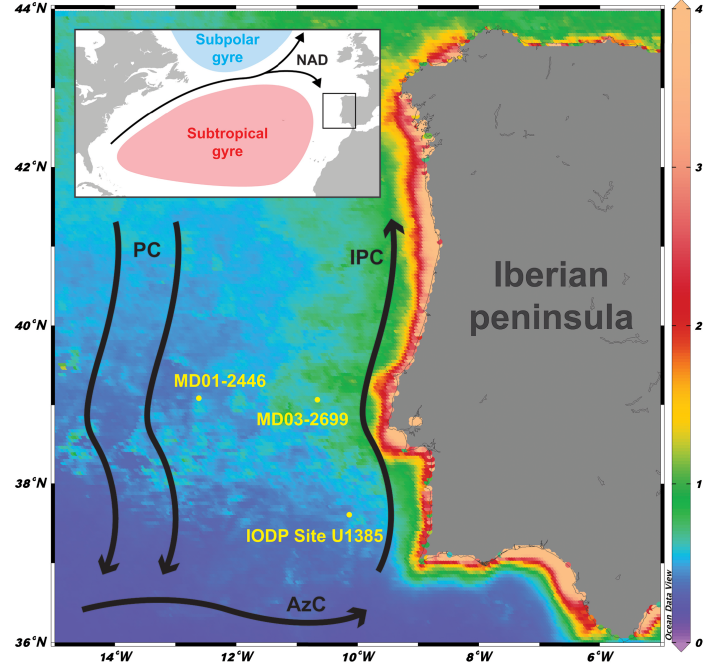

Figure 1. Core location and major currents in the area: NAD: North Atlantic Drift; PC: Portugal Current; IPC: Iberian Poleward Current; AzC: Azores Current. Background: chlorophyll $a$ concentration ( $\mathrm{mg} \mathrm{m}^{-3}$; March, April, and May average, 2003-2018) derived from MODISA satellite data available at http://disc.sci.gsfc.nasa. gov/giovanni (last access: 11 July 2018).

Fraga, 1981; Tenore et al., 2018). The upwelled water is the Eastern North Atlantic Central Water (ENACW), which has two different origins: a less saline, colder, nutrient-richer water mass of subpolar origin (ENACWsp) formed along with the Subpolar Mode Water in the Rockall Plateau region and a warmer, saltier, nutrient-poorer subtropical branch (ENACWst) formed along the Azores Front (Fiúza et al., 1984). Depending on the wind strength intensity either type can be upwelled (Fiúza et al., 1984), and in the current interglacial ENACWsp is mostly upwelled in the north-western coast of the Iberian peninsula, while ENACWst is mostly upwelled in the southern area of the western Iberian peninsula (Mason et al., 2006). The upwelling season typically lasts from late spring into summer (May to September), and upwelling filaments are mostly observed off the most prominent capes (Fiúza et al., 1982). Upwelling plumes and other mesoscale features can spread zonally offshore to distances of $200 \mathrm{~km}$ or more (Sousa and Bricaud, 1992). In autumn and winter the seasonal meridional shifts in the atmospheric highs revert the upwelling favouring equatorward winds to become poleward (Mason et al., 2006). The Azores High located further south and the Icelandic low intensification forces the wind regime to become more southerly, enabling the near-shore Iberian Poleward Current, which brings warmer and more oligotrophic waters from the Azores Current to the shelf and upper slope areas along the western IbM (Fiúza, 1983; Peliz et al., 2005; Vitorino et al., 2002). Downwelling can occur during this period but wintertime freshwater discharges from the major rivers are also a relevant feature, namely from the Tagus river that crosses the Iberian 
Peninsula, carrying a major load of suspended organic-rich sediments onto the continental shelf off Lisbon (Cabeçadas and Brogueira, 1998) and the Estremadura spur where our sediment core is located.

\subsection{Present coccolithophore productivity patterns in the $\mathrm{IbM}$}

Several studies on coccolithophore abundance and distribution (e.g, Abrantes and Moita, 1999; Cachão et al., 2000; Guerreiro et al., 2013; Moita, 2001) have been performed along the IbM, but only two were able to assess annual and seasonal productive cycles (Ausín et al., 2018; Silva, 2008; Silva et al., 2009). Maximum coccolithophores were found during spring and summer and associated with high irradiance levels (Ausín et al., 2017) and the convergence of warmer, more oligotrophic waters with the relaxation of northerly winds (Silva, 2008; Silva et al., 2009). Minimum absolute abundances, on the other hand, were observed during winter. The competitive dynamics between coccolithophores and diatoms are still not completely understood (Cermeño et al., 2011). Yet, these two main phytoplankton groups dominate the carbon dioxide mediation between the atmosphere and the ocean making them important contributors to the global carbon cycle. Diatoms are known to require more silica $(\mathrm{Si})$ and iron $(\mathrm{Fe})$ than coccolithophores (e.g. Merico et al., 2004), and Tyrrell and Young (2009) suggested that coccolithophore blooms might be associated with $\mathrm{Si}$ and Fe surface water depletion. Cermeño et al. (2011) suggested that coccolithophores could outcompete diatoms under steady-state nitrate limitation but under dynamical conditions (introducing nitrate pulses) diatoms outcompeted coccolithophores. They further found that the more frequent the pulses, the more rapidly diatoms outcompeted coccolithophores. The coastal upwelling conditions resemble these dynamical conditions, when pulses of nutrients are brought to the ocean surface. This could explain why Abrantes and Moita (1999) found a phytoplankton dominance of diatoms during upwelling events and a clear dominance of coccolithophores $(\sim 90 \%)$ during non-upwelling events. Also, Ausín et al. (2017) describe a decreasing abundance of diatoms with an increasing distance to shore, whereas coccolithophores showed higher abundances offshore than in coastal areas. This distribution pattern was maintained during the upwelling season (May to September), when coccolithophores are outcompeted by diatoms, in particular during the longer-lasting and more intense upwelling events (Moita, 2001; Silva et al., 2008).

Despite the general acceptance of coccolithophores as a single functional phytoplanktonic group associated with lowturbulence, low-nutrient, and high-irradiance environments, different species show varying life strategies. Several studies describe increased cell densities, mostly due to blooms of Emiliania huxleyi and Gephyrocapsa oceanica in the IbM (Moita, 2001; Guerreiro et al., 2013; Silva, 2008; Silva et al.,
2009), together with other fast-growing opportunistic phytoplankton genera, such as the diatoms Chaetoceros s.l., Thalassiosira s.1., and Skeletonema s.l. This corroborates coccolithophores' role among early succession taxa, or at least some species, capable of rapid growth in a nutrient-rich environment and most likely explains why Abrantes and Moita (1999) found coccolithophores' distribution in recent sediments to reflect their water column distribution during an upwelling situation and not the winter conditions.

\section{Material and methods}

\subsection{Sediment sampling and coccolith fraction separation}

In this study we used sediments of core MD03-2699 $\left(39^{\circ} 02.20^{\prime} \mathrm{N}, 10^{\circ} 39.63^{\prime} \mathrm{W} ; 1895 \mathrm{~m}\right.$ water depth), retrieved from a sediment drift, located ca. $100 \mathrm{~km}$ offshore, on the Estremadura promontory (Fig. 1). Sediments were collected using a giant CALYPSO piston corer on board the R/V Marion Dufresne II (PICABIA Cruise, 2003). The sedimentary record is mainly composed of hemipelagic silty clays. For our research, we use the age model published by Voelker et al. (2010).

For the $\mathrm{CF} \mathrm{Sr} / \mathrm{Ca}$ ratio, a total of 183 samples was analysed. Samples were taken at $4 \mathrm{~cm}$ spacing from the $\sim 7 \mathrm{~m}$ long section (from 1190 to $1898 \mathrm{~cm}$ core depth) corresponding to MIS 12 to MIS 9 ( $\sim 455$ to $310 \mathrm{ka})$. This resulted in a temporal resolution of $\sim 775$ years, although the oldest part has lower resolution due to the lower sedimentation rates (Rodrigues et al., 2011). To obtain the coccolith fraction (CF) $\mathrm{Sr} / \mathrm{Ca}$ record, $\sim 250 \mathrm{mg}$ of freeze-dried sample was collected and suspended in $2 \%$ ammonia (to avoid carbonate dissolution) and sieved through a $20 \mu \mathrm{m}$ mesh. This sieving aimed to separate the coccoliths contained in the so-called coccolith fraction $(<20 \mu \mathrm{m})$ from mostly foraminifera and their fragments and other larger microfossils or sediment components. All sieving material was carefully washed with running tap water and rinsed with distilled water in between samples to avoid cross contamination.

\subsection{Sample preparation and $\mathrm{Sr} / \mathrm{Ca}$ analysis}

We followed a three-step protocol to clean the sediment samples based on Stoll and Ziveri (2002):

1. the addition of $15 \mathrm{~mL}$ of MNX reagent $(75 \mathrm{mg}$ of hydroxylamine hydrochloride, $6 \mathrm{~mL}$ of concentrated ammonia, and $9 \mathrm{~mL}$ of ultrapure water) for a $12 \mathrm{~h}$ reaction in an automatic shaker; this step reduces $\mathrm{Fe}$ and Mn oxyhydroxides that scavenge metals from seawater and contain non-carbonate $\mathrm{Sr}$;

2. the addition of $2 \%$ ammonia to remove any noncarbonate $\mathrm{Sr}$, e.g. from clays, by exchanging cations $\left(\mathrm{Sr}_{2}^{+}\right)$with the excess of $\mathrm{NH}_{4}^{+}$;

3. three ultrapure water rinses to extract the ammonia. 
A weak buffered acid (6g glacial acetic acid, $7 \mathrm{~g}$ ammonium acetate in $1 \mathrm{~L}$ of Milli-Q water) was then used to dissolve the coccoliths, minimizing the contribution of ions from noncarbonate phases. The samples were left in acid for $12 \mathrm{~h}$ and the obtained solution was centrifuged, extracted, and kept in acid-cleaned centrifuge tubes. A first ICP-AES (inductively coupled plasma-atomic emission spectrometry) measurement of $\mathrm{Ca}$ was performed by diluting $100 \mu \mathrm{L}$ of the original sample $(2 \mathrm{~mL})$ into $2 \mathrm{~mL}$ of ultrapure Millipore water. The samples were subsequently diluted to $\mathrm{Ca}$ concentrations similar to the standard solutions. Calibration was conducted following the method described by de Villiers et al. (2002) using standards with constant $\mathrm{Ca}$ concentrations and different $\mathrm{Sr}$ concentrations to provide $\mathrm{Sr} / \mathrm{Ca}$ ratios ranging from 0.75 to $4 \mathrm{mmol} / \mathrm{mol}$. All measurements were conducted using the ICP-AES (Thermo ICAP DUO 6300) in the Geology Department at the University of Oviedo with a reproducibility better than $0.02 \mathrm{mmol} / \mathrm{mol}$. To infer any possible contamination other metals, such as $\mathrm{Fe}$ and $\mathrm{Mg}$, were also measured together with $\mathrm{Sr}$.

\subsection{Extraction of paleoproductivity record from the CF $\mathrm{Sr} / \mathrm{Ca}$ ratios}

Culture studies found a temperature dependence of coccolith $\mathrm{Sr} / \mathrm{Ca}$ with a $0.03 \mathrm{mmol} / \mathrm{mol}$ increase per degree Celsius rise (Müller et al., 2014; Stoll et al., 2002a). This signal can, however, be removed from the $\mathrm{Sr} / \mathrm{Ca}$ record using an independent SST reconstruction, so that the component of variation due to growth rate remains as residual (e.g. Cavaleiro et al., 2018; Mejía et al., 2014; (e.g. Cavaleiro et al., 2018; Mejía et al., 2014; Saavedra-Pellitero et al., 2017). The partitioning of $\mathrm{Sr}$ into the coccolith calcite varies among species (with larger and more heavily calcified coccoliths generally having a higher $\mathrm{Sr}$ content than smaller and lighter coccoliths; Fink et al., 2010; Stoll et al., 2007). Although it has been demonstrated that $\mathrm{CF} \mathrm{Sr} / \mathrm{Ca}$ ratios are not primarily controlled by variations in the coccolith assemblage in the modern ocean (Barker et al., 2006; Stoll and Schrag, 2000), the species composition, especially regarding the abundance of heavily calcified coccolithophores (e.g. Calcidiscus leptoporus, Helicosphaera carteri, Coccolithus pelagicus), should always be assessed. Our study period falls within the Gephyrocapsa caribbeanica acme (Baumann and Freitag, 2004; Bollmann et al., 1998), described between MIS 14/13 and MIS 8 when this species dominated $(\geq 50 \%)$ the coccolithophore community globally. In core MD03-2699, the gephyrocapsids contribute more than $92 \%$ to the flora (on average $97 \%$; Fig. 2; Amore et al., 2012), which minimizes the bias of the $\mathrm{CF} \mathrm{Sr} / \mathrm{Ca}$ data due to significant coccolith assemblage changes. The sum of the remaining coccoliths, which may contain the larger and Sr-rich coccoliths Calcidiscus leptoporus, Coccolithus pelagicus, and Helicosphaera carteri, averaged $2.8 \%$ (maximum $8.1 \%$, standard deviation $1.6 \%$ ). If we consider the abundance of the larger and Sr-rich coccol-

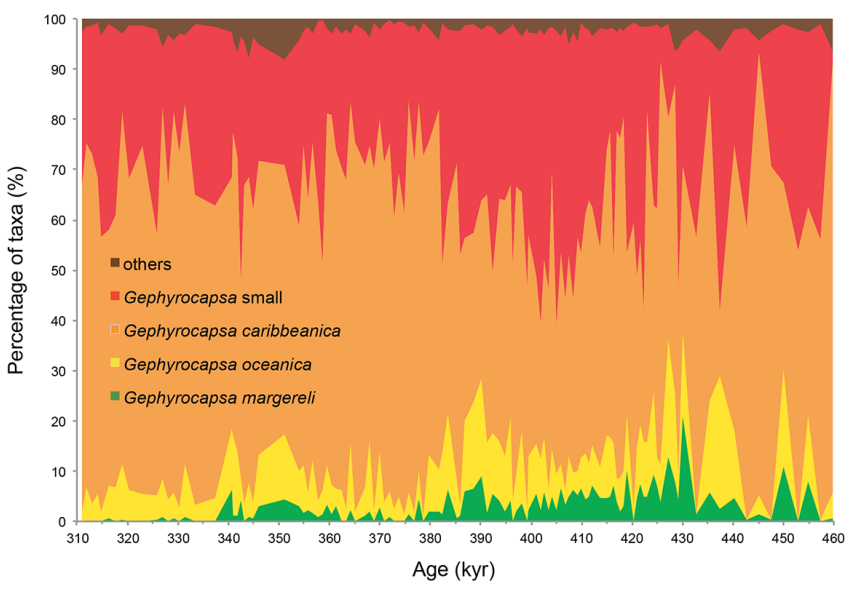

Figure 2. Composition of coccolith assemblages in core MD032699 based on Amore et al. (2012). Note that only a minor percentage of coccoliths belong to groups other than the dominant gephyrocapsids. The chronology is based on the age model of Voelker et al. (2010).

iths Calcidiscus leptoporus, Coccolithus pelagicus, and Helicosphaera carteri, the average and maximum abundances were, respectively, $1 \%$ and $3.6 \%, 0.1 \%$ and $0.3 \%$, and 0.2 and $1.5 \%$. Their contribution to the total $\mathrm{Sr}$ of the coccolith fraction is, therefore, negligible when compared to the gephyrocapsids' contribution.

With the assemblage changes considered we then moved to the temperature effect extraction. This was extracted from the CF Sr/Ca ratios record following Mejia et al. (2014) and Cavaleiro et al. (2018). We used the multi-species temperature dependence to calculate an SST-predicted $\mathrm{Sr} / \mathrm{Ca}$ curve, and the extraction of the temperature effect consisted in subtracting the SST-predicted $\mathrm{Sr} / \mathrm{Ca}$ values from the initial CF $\mathrm{Sr} / \mathrm{Ca}$ ratios in Eq. (1):

$\mathrm{CF} \frac{\mathrm{Sr}}{\mathrm{Ca}}-\mathrm{SST}$ predicted $\frac{\mathrm{Sr}}{\mathrm{Ca}}=\mathrm{CF} \frac{\mathrm{Sr}}{\mathrm{Ca}}$ residual.

We calculated the temperature dependence using the $\mathrm{U}_{37}^{K^{\prime}}$ based SST record of core MD03-2699 for the same period (Rodrigues et al., 2011). The alkenones present in the sediments are today mostly produced by a few species of the class Prymnesiophyceae, mainly by the coccolithophores Emiliania huxleyi and Gephyrocapsa oceanica (Prahl et al., 1988; Prahl and Wakeham, 1987), and the $\mathrm{U}_{37}^{K^{\prime}}$-based SST is therefore the best estimator of coccolithophores' habitat temperature. After extraction of the temperature influence, the resultant residual mainly represents coccolithophore calcification and growth rate and consequently coccolithophore longterm productivity fluctuations. We refer to the $\mathrm{Sr} / \mathrm{Ca}$ residual as coccolithophore productivity because after correcting for the temperature changes, we expect the data to mostly reflect coccolithophore calcification and growth rate and thus their paleoproductivity qualitatively. This coccolithophore 
productivity record reflects relative productivity change, representing the productivity deviation around the average productivity of the time series.

An uncertainty envelope/confidence interval for the $\mathrm{CF}$ $\mathrm{Sr} / \mathrm{Ca}$ residual estimation (shown as a grey envelope in Fig. 3) was calculated using Astrochron (Meyers, 2014) where the upper and lower limits correspond to the Monte Carlo 20 and $80 \%$ confidence interval, respectively. One hundred Monte Carlo simulations were run for each of the 183 data points carrying out propagation of errors accounting for uncertainties measurement of: (1) temperature (with $\sigma=1.5^{\circ} \mathrm{C}$ ); (2) $\mathrm{Sr}$ concentration (with $\sigma=0.02 \mathrm{mmol} / \mathrm{mol}$ ); and (3) the linear regression of temperature versus $\operatorname{Sr}(\sigma=$ $0.12 \mathrm{mmol} / \mathrm{mol}$ ).

\section{Results}

\subsection{Potential influence of detrital carbonate on the CF $\mathrm{Sr} / \mathrm{Ca}$ data}

When present, detrital carbonate could negatively bias any $\mathrm{CF} \mathrm{Sr/Ca} \mathrm{ratio} \mathrm{(and} \mathrm{any} \mathrm{coccolithophore} \mathrm{productivity} \mathrm{recon-}$ struction) by increasing the background carbonate in relation to the coccolith carbonate. In our study, we considered potential sources of detrital carbonate biasing the $\mathrm{CF} \mathrm{Sr} / \mathrm{Ca}$ results: (1) ice-rafted debris (IRD) discharged by melting icebergs, (2) aeolian input, and (3) riverine discharge. Deposition of carbonate/dolomite-rich IRD is linked to extremely cold and lower-salinity conditions (Fig. 4), namely Heinrichtype events (HtEs; Andrews and Voelker, 2018; Hodell et al., 2008; Rodrigues et al., 2011; Salgueiro et al., 2010; Stein et al., 2009). Ice-rafted material, especially the fine-grained material, also contains reworked coccoliths, which can be Tertiary or Cretaceous in age (Marino et al., 2011, 2014; Rahman, 1995). Increased aridity and wind conditions enhance aeolian transport (e.g. Bozzano et al., 2002), which can transport detrital carbonate material, coming mostly from North Africa (e.g. Negral et al., 2012; Stumpf et al., 2010), to the $\mathrm{IbM}$. On the other hand, increased moisture and precipitation intensifies rock weathering and riverine discharge, raising fluvial transport of detrital carbonate onto the IbM (Hodell et al., 2017; Hodell and Channell, 2016). However, the IbM documents that an increased detrital carbonate presence is prevalent during cold and arid rapid millennial-scale events related to low sea-level stands and IRD events (Lebreiro et al., 2009; Marino et al., 2011; Hodell et al., 2013, 2017; and Hodell and Channell, 2016).

In order to evaluate this potential biasing effect we match the $\mathrm{CF} \mathrm{Mg} / \mathrm{Ca}$ values in a cross-plot with the $\mathrm{CF} \mathrm{Sr} / \mathrm{Ca}$ results. We used $\mathrm{CF} \mathrm{Mg} / \mathrm{Ca}$ because $\mathrm{Mg} / \mathrm{Ca}$ peaks can be attributed to the presence of increased detrital carbonate, such as dolomite $\left(\mathrm{CaMg}\left(\mathrm{CO}_{3}\right)_{2}\right)$. The $\mathrm{Mg} / \mathrm{Ca}$ threshold was defined at $30 \mathrm{mmol} / \mathrm{mol}$ because from that point onwards both $\mathrm{CF} \mathrm{Mg} / \mathrm{Ca}$ and $\mathrm{Sr} / \mathrm{Ca}$ show a clear negative relationship; i.e. $\mathrm{CF} \mathrm{Mg} / \mathrm{Ca}$ increases when $\mathrm{CF} \mathrm{Sr} / \mathrm{Ca}$ clearly decreases
(Fig. 5a). Therefore the samples highlighted in Fig. 5b with a red circle were considered possibly contaminated by detrital carbonate. We estimate that (i) $16 \%$ of the samples might have been biased by the presence of detrital carbonate and confirm that (ii) such samples are linked to rapid millennialscale and low sea-level stands, namely during substages MIS 10a, MIS 12a, and the respective subsequent terminations V and IV (Fig. 4). Although a possible bias effect exists in such samples, it does not prove that coccolith $\mathrm{Sr} / \mathrm{Ca}$ ratio and coccolithophore productivity were not indeed significantly lower during those intervals (see Discussion). We have considered the bias from reworked coccolith contribution to be negligible because reworked coccolith abundance was generally below $2 \%$, not only in our study site (Amore et al., 2012) but also at other IbM sites for the same time interval (Maiorano et al., 2015; Marino et al., 2014).

\subsection{Coccolithophore productivity results}

The $\mathrm{CF} \mathrm{Sr} / \mathrm{Ca}$ ratio results varied between 1.2 and $2.4 \mathrm{mmol} / \mathrm{mol}$ (sampling range of $1.16 \mathrm{mmol} / \mathrm{mol}$ ) with $85 \%$ of the samples falling between 1.8 and $2.3 \mathrm{mmol} / \mathrm{mol}$. The $\mathrm{Sr} / \mathrm{Ca}$ residual, from now on referred to as coccolithophore productivity (CP), generally mimics the $\mathrm{CF} \mathrm{Sr} / \mathrm{Ca}$ ratio record and shows minima and maxima at the same levels (Fig. 3). The high $\mathrm{CF} \mathrm{Sr/Ca} \mathrm{ratios} \mathrm{found} \mathrm{in} \mathrm{the} \mathrm{record} \mathrm{do}$ not coincide with increased abundance of large/Sr-rich coccoliths (Fig. 2) or with higher temperatures (Fig. 3). This supports the statement that our $\mathrm{CF} \mathrm{Sr} / \mathrm{Ca}$ variation reliably records coccolithophore calcification rate and productivity changes. Both MIS 12 and MIS 10 are characterized by higher $\mathrm{CP}$ during the first half and lower productivity towards the second half. Large and rapid increases in $\mathrm{CP}$ characterize the deglaciations at the end of MIS 12 and MIS 10.

To better visualize and interpret the $\mathrm{CF} \mathrm{Sr} / \mathrm{Ca}$ results, the $\mathrm{CP}$ data were divided into three relative intervals. An "intermediate" interval is defined by the mean of the data plus and minus half of the standard deviation. The "high" and "low" CP levels are above and below the intermediate level of CP, respectively (highlighted by green and blue shading in figures, respectively). We would like to stress that our study focuses on the qualitative characteristics of the coccolithophore paleoproductivity record rather than quantitatively estimating the productivity of coccolithophores.

A preliminary visual inspection of the record already allows the identification of higher-amplitude events during glacial substages MIS 12b and 12a and MIS 10b and 10a in comparison to the less variable interglacial substages MIS $11 \mathrm{c}$ and MIS 9e. CP maxima happened during the first half of MIS 12 and MIS 10 and during the transition from interglacial to glacial substages (Fig. 3). Productivity minima, on the other hand, occurred during glacial maximum substages MIS 12a and MIS 10a and at the end of MIS 11a. Marine Isotope Stages $11 \mathrm{c}$ and 9e, commonly known as the interglacial substages (Past Interglacials Working Group 


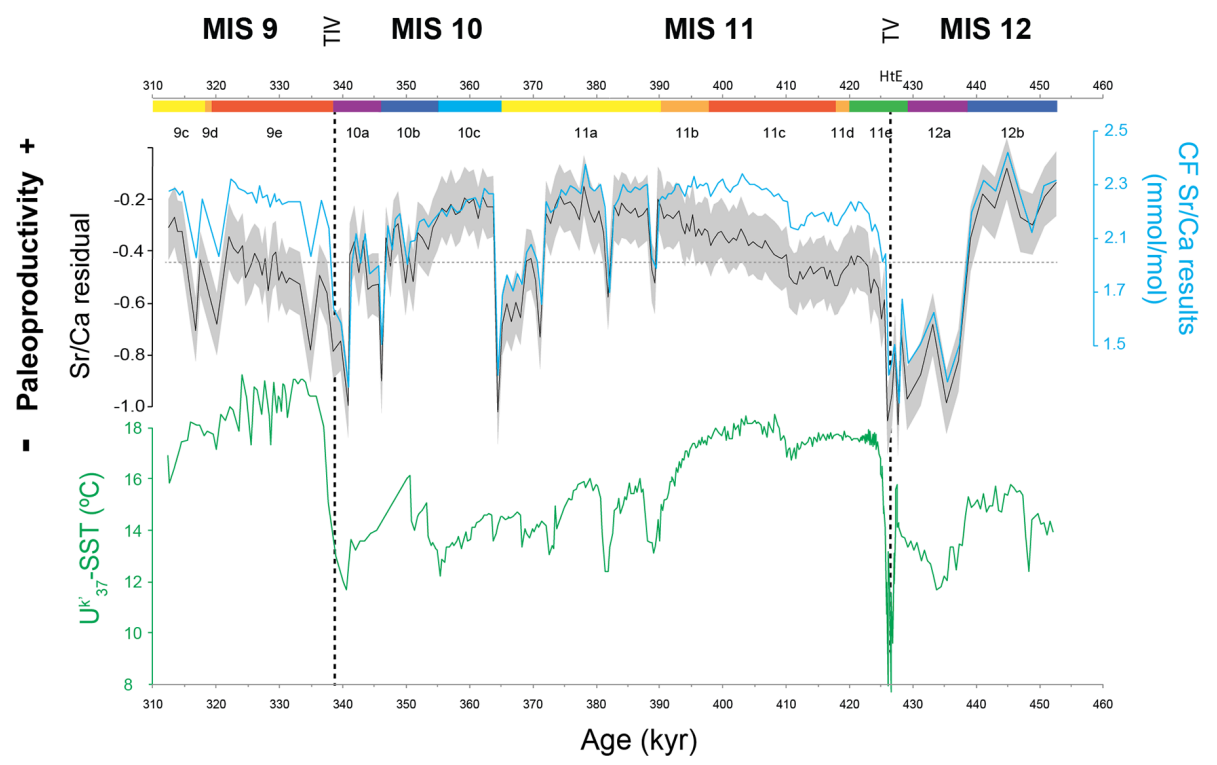

Figure 3. Coccolithophore paleoproductivity results from core MD03-2699: coccolith fraction (CF) Sr/Ca ratio and the resulting CF Sr/Ca residual with confidence interval (grey shading represents Monte Carlo $20 \%-80 \%$ interval) and $\mathrm{U}_{37}^{k^{\prime}}$-based reconstruction of sea surface temperature (Rodrigues et al., 2011). The horizontal dashed line marks the average value for CF Sr/Ca and CF Sr/Ca residual. The chronology is based on the age model of Voelker et al. (2010), Marine isotope stages (MISs) and substages marked according to Railsback et al. (2015); vertical dashed lines highlight terminations V and IV.

of PAGES, 2016), mainly show periods of lower-amplitude changes within an intermediate level of $\mathrm{CP}$ when compared to the rest of the record. Rodrigues et al. (2011) mentioned a similar SST pattern, on the same time frame and at the same site, which could imply SST is an important factor affecting CP.

\section{Discussion}

\subsection{Causes for CP change}

\subsubsection{High CP levels during the transition from interglacial to glacial periods}

CP increased steadily from mid-MIS 11c until the end of MIS $11 \mathrm{~b}$ and remained generally high from late MIS $11 \mathrm{c}$ to MIS 10c, prior to the glacial substages within MIS 10 and MIS 12. We suggest this increasing $\mathrm{CP}$ is a consequence of a gradual rise in nutrient availability due to either enhanced northerly winds and upwelling strength or due to the decreasing influence of subtropical waters, substituted by increasing influence of transitional nutrient-richer surface waters (i.e. ENACWsp). During interglacial substages, such as MIS 11c and MIS 9e, the wind stress associated with the upwelling events has been suggested to be lower than during glacial substages in the IbM (e.g. Salgueiro et al., 2010). This is based on the observation that along with the expansion of the Northern Hemisphere continental ice sheets, atmospheric and oceanic circulation changed leading to a narrowed latitudinal temperature gradient and po- tentially enhanced northerly winds and upwelling intensity (Broccoli et al., 2006; Hostetler et al., 1999). Note, however, that for upwelling to be intensified during transitions from interglacial to glacial substages and during glacials substages, it would have required that the atmospheric circulation pattern governed by the relative position and gradients between high- and low-pressure centres have remained similar to today (i.e. interglacial substage). Based on differences in the planktonic oxygen isotope records of cores MD03-2699 and MD01-2446 (more offshore) (Fig. 1), Voelker et al. (2010) suggested that the higher variability in our core, MD032699 , could reflect variations in the upwelling of deeper waters into the thermocline. Stronger winds would favour upwelling intensification, which could lead to the upwelling of the deeper, nutrient-richer ENACWsp on the IbM (Fiúza, 1984), as already suggested for some Late Pleistocene periods (Salgueiro et al., 2010, 2014). Still, the transition period is characterized by a decrease in SSTs most likely already reflecting the southward displacement of the North Atlantic frontal system and, consequently, increasing the influence of an ENACWsp origin, more nutrient rich than an ENACWst origin, in the surface water of western IbM. Increased nutrient availability would thus support an increase in productivity of the whole phytoplankton community (Álvarez-Salgado et al., 1997; Guerreiro et al., 2013), and after depletion of silica by diatoms, coccolithophore species capable of rapid growth, as Gephyrocapsa caribbeanica is thought to have been, given its cosmopolitan distribution and dominance in the sediments (Baumann and Freitag, 2004; Bollmann et al., 


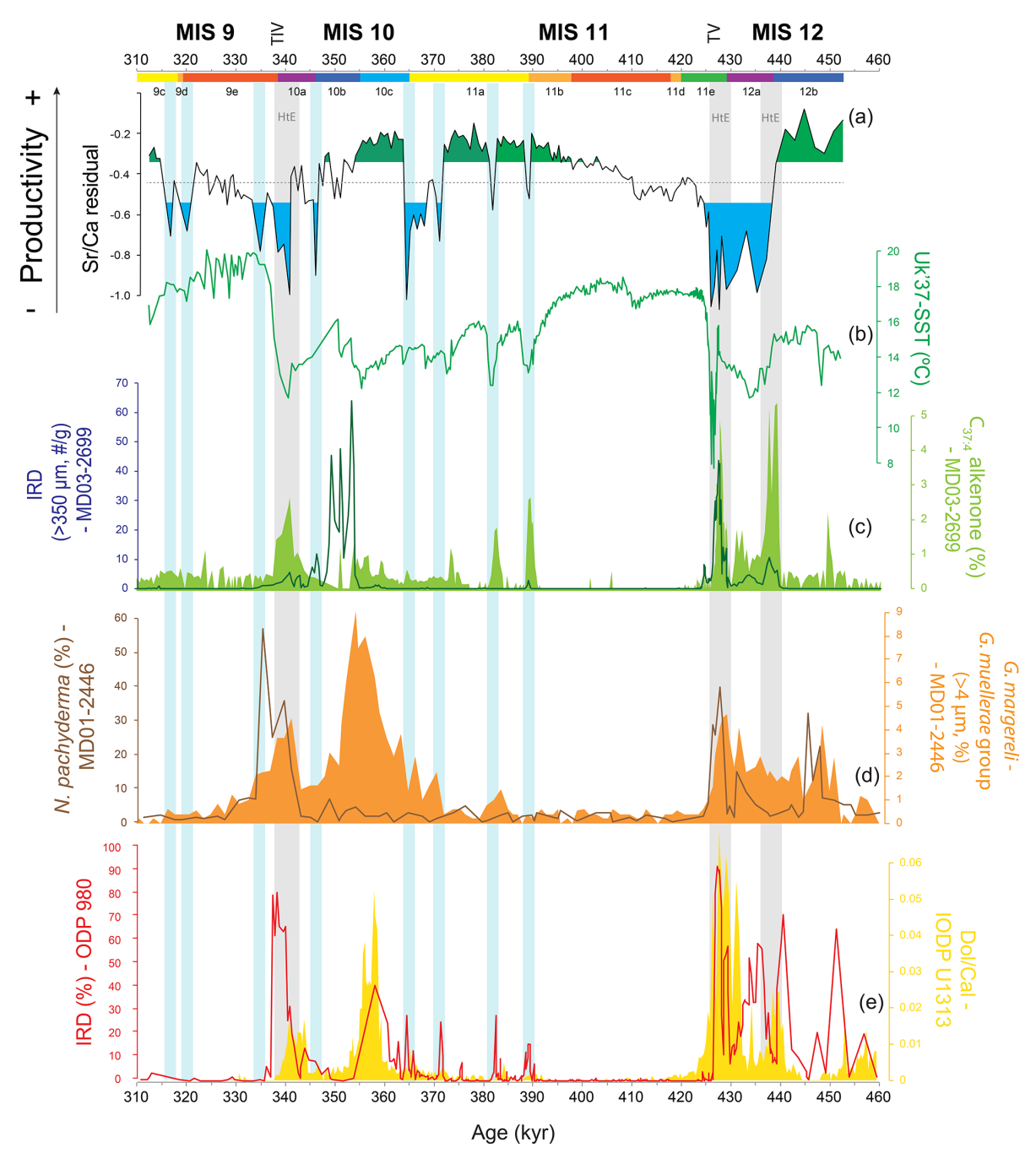

Figure 4. Coccolithophore paleoproductivity reconstruction with "high" and "low" coccolithophore productivity levels highlighted in green and blue shading, respectively (a), compared to (b) $\mathrm{U}_{37}^{k^{\prime}}$-based reconstruction of sea surface temperature from core MD03-2699 (Rodrigues et al., 2011); (c) ice-rafted debris (IRD) abundance (Voelker et al., 2010) and heptatriatetraenone ( $\mathrm{C}_{37: 4}$ alkenone) abundance (Rodrigues et al., 2011), both from core MD03-2699; (d) Neogloboquadrina pachyderma relative abundance and Gephyrocapsa margereli and G. muellerae group relative abundance, both from core MD01-2446 (Marino et al., 2014); (e) percentage IRD from ODP Site 980 (McManus et al., 1999) and dolomite/calcite ratio from IODP Site U1313 (Stein et al., 2009). Note that the MD03-2699 lithic fragments were counted in a coarser size fraction $(>315 \mu \mathrm{m})$ than the standard size fraction $(>150 \mu \mathrm{m}$; Hemming, 2004) and thus most likely only record major ice-rafting events at the IbM, as suggested by Marino et al. (2014). Chronology as in Fig. 3. Vertical bars: grey bars correspond to Heinrich-type events (HtEs) and blue bars to short-lived events of decreased coccolithophore productivity.

1998), could bloom. It is important to refer that such CP maxima would only be possible if bioavailable $\mathrm{Si}$ and $\mathrm{Fe}$ were not sufficiently high for diatoms to outcompete coccolithophores until complete nutrient depletion. Maybe seasonality could also have played an important role here (see intermediate CP level discussion below). As coccolithophores perform better in stable and continuously nutrient-replenished surface waters, in contrast with diatoms that thrive in dynamical (e.g. upwelling) conditions, (Cermeño et al., 2011), we believe that, during the transition to full glacial conditions, persistent and increasing nutrient replenishment on the IbM was more related to the advection of transitional waters of subpolar origin than to increased upwelling. Finally, our high CP supports the idea that the coccolithophore community was able to better perform under these transitional conditions, despite colder SST, and possibly more turbulent settings than during interglacial substages. Noteworthy is the fact that this maximal CP interval was frequently interrupted by abrupt cooling events (Fig. 6) when CP also abruptly decreased. Though detrital carbonate influence cannot be excluded (see methodology), such CP reductions might indicate that coccolithophore productivity was close to its lowest SST threshold and that 


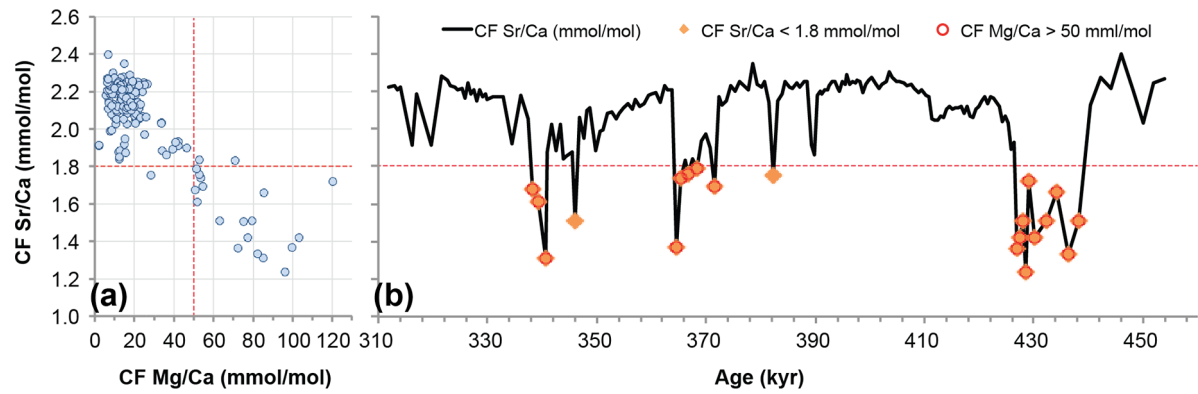

Figure 5. Detrital carbonate analysis: (a) coccolith fraction (CF) Sr/Ca results and CF Mg/Ca cross-plot (vertical red line delimits threshold at $30 \mathrm{mmol} / \mathrm{mol}$ of $\mathrm{Mg} / \mathrm{Ca}$ ); (b) $\mathrm{CF} \mathrm{Sr} / \mathrm{Ca}$ samples possibly contaminated with detrital carbonate (red makers) and notably associated millennial abrupt events.

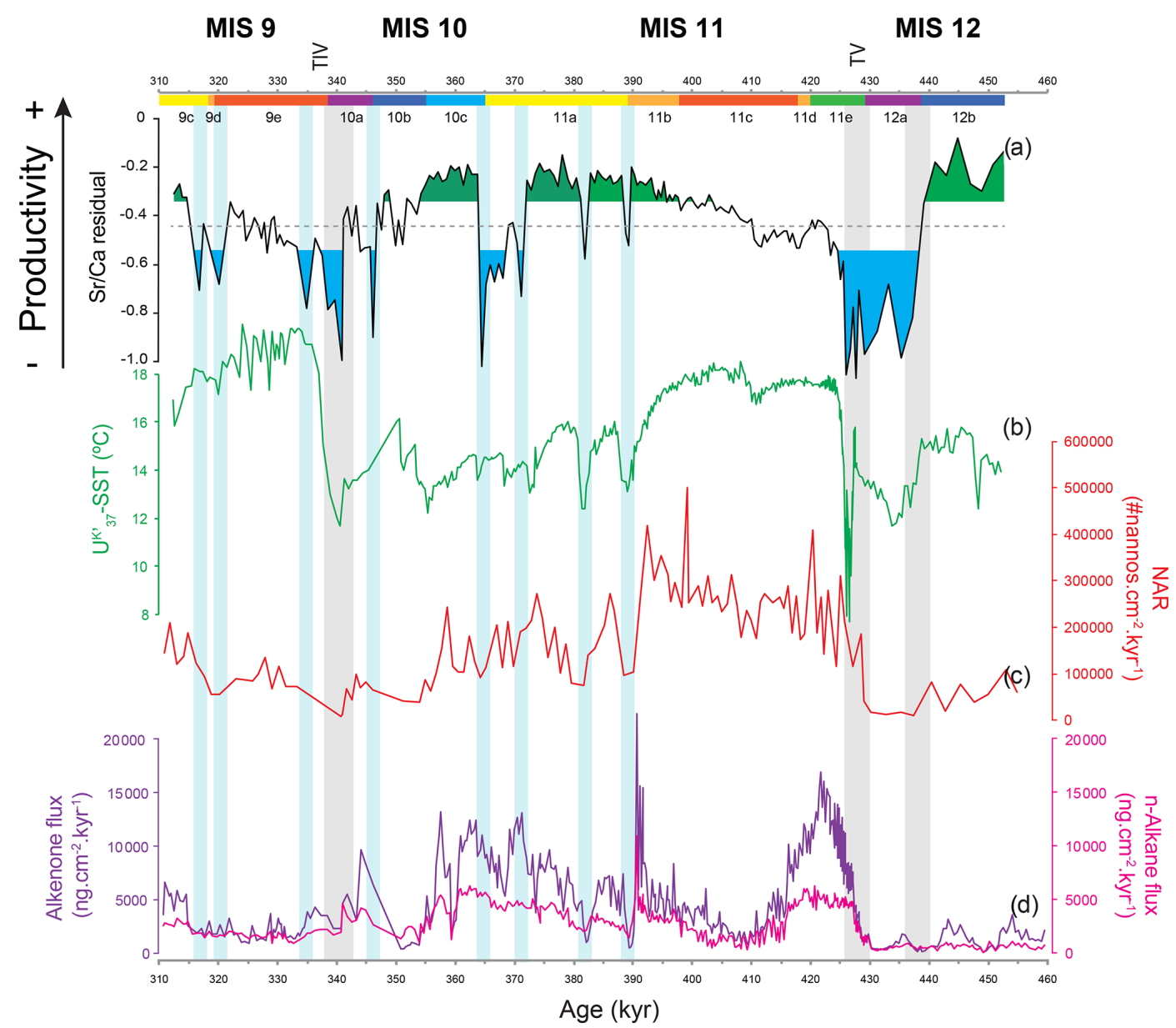

Figure 6. Coccolithophore paleoproductivity reconstruction with "high" and "low" CP levels highlighted in green and blue shading, respectively (a), compared to (b) $\mathrm{U}_{37}^{k^{\prime}}$-based reconstruction of sea surface temperature (Rodrigues et al., 2011), (c) nannofossil accumulation rate (NAR) (Amore et al., 2012), and (d) total alkenone (AlkAR) and $n$-alkane accumulation rates (Rodrigues et al., 2011). Chronology as in Fig. 3. Vertical bars: grey bars correspond to Heinrich-type events (HtEs) and blue bars to short-lived events of decreased CP. 
abrupt drops in SST immediately resulted in abrupt CP declines.

\subsubsection{Intermediate CP levels associated with deglaciations and interglacial periods}

The rapid $\mathrm{CP}$ increase during deglaciation is contemporary with a rapid SST rise (T V and T IV; Fig. 3). The deglacial SST increase and the subsequent particularly stable SSTs during MIS 11c (and most likely MIS 9e) recorded in our MD03-2699 core are linked to the increasing influence and dominance of subtropical oligotrophic waters from the Azores and Iberian Poleward Currents (Rodrigues et al., 2011; Voelker et al., 2010). Several IbM sites support this with increased abundance of warm coccolith taxa (site MD03-2699; Amore et al., 2012 and Palumbo et al., 2013a; IODP Site U1385, Maiorano et al., 2015; site MD01-2446, Marino et al., 2014) and of tropical planktonic foraminifera species Globorotalia menardii and Sphaeroidinella dehiscens (site MD03-2699; Voelker et al., 2010; site MD01-2443, de Abreu et al., 2005) during the deglaciations and MIS $11 \mathrm{c}$ and MIS 9e. Despite the large amplitude change in the CP during the deglaciation, a comparably larger amplitude change is associated with glacial substage MIS 12a and the transitional substage MIS 11b, when SSTs were comparably lower than during MIS 11c (see previous subchapter). Thus, we suggest that during the deglaciation CP increased sharply because of the amelioration of the oceanographic conditions (mostly due to increasing SST) but their productivity was limited to intermediate levels of productivity because of either limited nutrient supply from the prevalent advected subtropical oligotrophic waters or upwelled waters (1) and/or increased competition for nutrients with diatoms (2), which mostly affected the coccolithophore species with opportunistic and fast-growing characteristics (r-selected species) such as gephyrocapsids. Such competition with diatoms could be related to upwelling intensity (Cermeño et al., 2011) during interglacial substages MIS 11c and MIS 9e. During the current interglacial, upwelling only happens in the IbM during the spring-summer months, when winds, mostly driven by trade winds, are strong and predominantly from the northnorthwest (Fiúza et al., 1982; Fiúza, 1983; Mason et al., 2006). Given the current variability in the western IbM (Alvarez et al., 2008; Arístegui et al., 2009) and its dependency on changes in the regional atmospheric circulation, especially related to the latitudinal migration of the subtropical front and to the dynamics of the Azores anticyclonic cell (Arístegui et al., 2009; Fiúza et al., 1982; Mason et al., 2006), it is difficult to assert what has been the wind regime and upwelling seasonality during the deglaciations. However, when assessing the hypothesized upwelling strength between interglacial and glacial substages, and in the event of lower nutrient availability for the rest of the year, coccolithophores would be easily outcompeted by diatoms, as in the upwelling event of the current interglacial (e.g. Abrantes and Moita, 1999).

This evidence suggests that irrespective of the upwelling regime that influenced seasonal overall nutrient availability and phytoplanktonic productivity, the intermediate levels of CP could be explained by a competitive advantage of diatoms upon sufficient delivery of $\mathrm{Si}$ and $\mathrm{Fe}$ of terrigenous input, either by increased aeolian input or riverine discharge. Since changes in the SST and nutrient availability are not only promoted by fluctuations in the upwelling regime (1) and changes in the advection of the dominant water masses (2) in the IbM, we also considered changing seasonality, i.e. changes in precipitation (3) and arid plus windy (4) conditions to have played a role in determining CP. It is well known that the addition of $\mathrm{Fe}$ into the surface ocean positively affects the overall phytoplankton community (Blain et al., 2004; Martin et al., 1990). And diatoms require more Si and $\mathrm{Fe}$ (e.g. Merico et al., 2004), whereas coccolithophore blooms are thought to be linked with $\mathrm{Si}$ and $\mathrm{Fe}$ depletion (Merico et al., 2004; Tyrrell and Merico, 2004) giving coccolithophores a competitive advantage in an $\mathrm{Si}$ and Fe depletion scenario with plenty of other nutrients, such as nitrate and phosphate. Thus, under fluctuating nutrient availability and increased bioavailability of $\mathrm{Si}$ and $\mathrm{Fe}$ (Capellacci et al., 2013), diatoms could have outcompeted coccolithophores via nutrient competition, limiting coccolithophore growth to intermediate levels of productivity after diatom bloom. Periods of strengthened wind regime and aridity are generally limited to glacial substages and stadials (Desprat et al., 2009, 2017; Hodell et al., 2013b; Oliveira et al., 2016; Sánchez Goñi et al., 2016). But, Rodrigues et al. (2011) interpreted the synchrony between high terrigenous input (concentration of n-alkanes) and alkenone concentration in core MD032699 (Fig. 6d) with intensified dust export from North Africa (based on Fe counts at Site 958 off western North Africa; Helmke et al., 2008) as indicative of a strong wind regime in the IbM during the deglaciation and early phase of MIS 11c. However such high Fe counts evidencing strong winds are referred by Helmke et al. (2008) for the deglaciation but not for MIS 11d and early MIS 11c, where the same study suggests a humid period in North Africa associated with increased precipitation and a widespread vegetation cover. So during the deglaciation such strong winds might have been sufficient to replenish the surface waters with $\mathrm{Si}$ and $\mathrm{Fe}$, allowing diatoms to bloom (Abrantes, 2000; Capellacci et al., 2013) and outcompeting coccolithophores. And, in the early MIS11c, Si and $\mathrm{Fe}$ could have also come into the IbM through riverine discharge.

Under full interglacial conditions, pollen records evidence the development of temperate and humid deciduous forest in north-western Iberia (Desprat et al., 2007), which during MIS 11c coincided with the North African humid period described by Helmke et al. (2008). Based on the increased abundance of Mediterranean forest taxa observed in southwest IbM IODP Site U1385, Oliveira et al. (2017) associated 
climate during MIS 11c with the present-day SW Iberian climate, i.e. with pronounced seasonality between warm and dry summers and cool and wet winters. The warmer and drier summers, tied to the north-eastwardly expansion of the Azores subtropical High, associated with the descending branch of the Hadley cell (Lionello et al., 2006; Oliveira et al., 2017), could have enabled dust flux to the western IbM. During winters, on the other hand, nutrients in the surface waters could have been replenished by increased precipitation and associated river run-off, in agreement with the expansion of temperate humid forest. So, during interglacials, our theory that periods when CP seemed limited to intermediate levels are linked to conditions of increased terrigenous input, either aeolian or riverine, that allowed diatoms to outcompete coccolithophores is also valid.

\subsubsection{Low CP associated with abrupt cooling events and glacial MIS 12a}

$\mathrm{CP}$ shows consistent minima along the record that, with the exception of glacial maximum stage MIS 12a and the $\sim 10 \mathrm{kyr}$ interval at the transition from MIS 11a to MIS $10 \mathrm{c}$, are of short duration and related to abrupt climate change events. Thus, most of the minima coincide with the presence of colder and less saline surface waters that resulted from meltwater incursions onto the IbM evidenced either by the increased IRD content or higher percentages of $\mathrm{C}_{37: 4}$ alkenones, concomitant with higher abundances of coccoliths belonging to Gephyrocapsa margereli-G. muellerae ( $>4 \mu \mathrm{m}$ ), a cold/low-salinity water proxy in the IbM (Fig. 4; Marino et al., 2014; Rodrigues et al., 2011). The most extreme of these events are the HtEs (Stein et al., 2009; Fig. 4), with the ones during $\mathrm{T}$ IV and $\mathrm{T} \mathrm{V}$ corresponding to the terminal stadial events of Hodell et al. (2015). The associated cooling brought the SSTs nearly to local glacial levels (Fig. 4; Rodrigues et al., 2011). Similar to their counterparts during the last glacial cycle, the meltwater events resulted in an accentuated decrease or nearly the elimination of the Atlantic Meridional Overturning Circulation and in a southwards displacement of the North Atlantic frontal system with the subpolar/arctic front moving into IbM latitudes (AlonsoGarcia et al., 2011; Hodell et al., 2008; McManus et al., 1999; Rodrigues et al., 2011, 2017). This led to the advection of polar and subpolar water masses onto the IbM evidenced by the increased percentage of polar planktonic foraminifera Neogloboquadrina pachyderma in the nearby core MD012446 (Fig. 4; Marino et al., 2014) and in cores off Galicia (Desprat et al., 2007, 2009).

The abrupt CP drops at $438 \mathrm{ka}$ and at $340 \mathrm{ka}$ prior to and during $\mathrm{T} \mathrm{V}$ and $\mathrm{T} \mathrm{IV}$, respectively, are both related to HtEs (Fig. 4). As previously mentioned, during HtEs detrital carbonate might have negatively biased our CP. However, detrital carbonate might have acted as a low-productivity signal amplifier instead of attributing false low CP in such intervals. An extreme decline in $\mathrm{CP}$ during the TV HtEs/terminal stadial event was also observed at IODP Site U1313 in the central North Atlantic basin (Cavaleiro et al., 2018). During those events the abrupt SST decrease coupled with increased turbidity and blockage of sunlight (due to melting icebergs and/or sea ice cover) would have decreased the coccolithophores' ability to survive. These conditions resemble those in the present-day polar domain of the NorwegianGreenland Sea (Baumann et al., 2000). Here, a less diverse coccolithophore community was observed with a slightly diminished coccolithophore population, which could well support the abrupt decreases detected in our CP record.

Additional CP minima are detected at 389, 382, 371, 364 (the latter dropping to HtE levels; Fig. 4), 346, 334, 319, and $316 \mathrm{ka}$. Despite no significant concomitant IRD peaks in core MD03-2699, these decreases are associated with increases in the abundance of the $\mathrm{C}_{37: 4}$ alkenone and colder SST (Fig. 4; Rodrigues et al., 2011) and the presence of $N$. pachyderma and G. margereli-G. muellerae $(>4 \mu \mathrm{m})$ in core MD01-2446 (Fig. 4; Marino et al., 2014), testifying to a rapid change to significantly colder and less saline conditions at this latitude. The four older drops in CP happened concomitantly with abrupt increases in Neogloboquadrina pachyderma abundance at ODP Site $980\left(55^{\circ} 29^{\prime} \mathrm{N}, 14^{\circ} 42^{\prime} \mathrm{W}\right)$ in the eastern North Atlantic (Fig. 4; McManus et al., 1999; Oppo et al., 1998), placing them in a broader spatial scale of climate deterioration. Thus, we conclude that the IbM was subjected to drastic surface water changes that led to a coccolithophore community decrease in the IbM and generated abrupt decreases in our $\mathrm{CP}$ record.

Finally, the reduced productivity during MIS 12a at the location of core MD03-2699 is in stark contrast to the openocean record of IODP Site U1313 (Cavaleiro et al., 2018) and other past glacial periods in the IbM such as MIS 2 and MIS 6 (Salgueiro et al., 2010, 2014), all of which point to increased productivity during the glacial maxima. Furthermore, such prolonged low $\mathrm{CP}$ is also not observed during glacial maximum MIS 10a, when productivity at site MD03-2699 remained at intermediate levels between abrupt cold events (Fig. 4). However, the prolonged presence of (sub)polar waters in the eastern North Atlantic throughout MIS 12a is backed up by the IRD record and persistent high percentages of N. pachyderma (Oppo et al., 1998; McManus el al., 1999) at ODP Site 980 and in core MD01-2448 in the Bay of Biscay (Toucanne et al., 2009). It is thus likely that such low-temperature, and eventually salinity, water masses also affected the IbM, hampering upwelling (enhanced upwelling is seen as the cause for increased productivity at the IbM during glacial maxima; Abrantes et al., 2000; Salgueiro et al., 2010,2014 ) and potentially leading to a low CP. 


\subsection{Evidence from different coccolithophore productivity proxies and conceptual models}

Previous studies in the IbM used coccolith-derived proxies, such as coccolith assemblages, NARs, and total alkenone fluxes (produced mostly by coccolithophores) to reconstruct changes in coccolithophore paleoproductivity (Amore et al., 2012; Maiorano et al., 2015; Marino et al., 2014; Palumbo et al., 2013). These traditional proxies depend not only on the supply of coccoliths or organic compounds but also on dilution by minerals and other sediment constituents and on changing preservation conditions (Rullkötter, 2006). As the $\mathrm{CF} \mathrm{Sr} / \mathrm{Ca}$ ratio is an independent proxy, i.e. independent of sedimentation and accumulation rates, it offers a new perspective on $\mathrm{CP}$ dynamics and the opportunity to compare coccolithophore growth/calcification rate (referred to here as coccolithophore productivity) with other components of the system. In a simple time series comparison of our CP data with the NAR or the AlkAR records we can already confirm that their relationship is not straightforward (Fig. 6). While in some intervals CP, NAR, and AlkAR show similar trends, in others they diverge.

As mentioned previously, several studies have hypothesized a relevant role of coccolithophores on the global carbon and carbonate cycles and on the glacial-interglacial dynamics (Duchamp-Alphonse et al., 2018; McClelland et al., 2016; Omta et al., 2013; Rickaby et al., 2007; Saavedra-Pellitero et al., 2017). Yet, the inclusion of biogeochemical processes related to coccolithophores in Earth system models is lacking, although they play a role in both the organic (soft tissue) and the carbonate counter pump (through calcification). Coccolith carbonate also has a ballasting effect, enhancing the $\mathrm{C}_{\text {org }}$ export efficiency (Armstrong et al., 2001; Francois et al., 2002), but the relative proportion of exported particulate organic carbon to inorganic carbon is difficult to predict and model (Barker et al., 2006; Ridgwell and Zeebe, 2005). Therefore, the respective and relative importance of these mechanisms is still poorly understood and the past and future net impact of calcification by coccolithophores on atmCO $\mathrm{CO}_{2}$ is still uncertain (Lawton et al., 2003). Among the difficulties in modelling coccolithophores' responses are the complex interactions between coccolithophore productivity and growth rates and nutrient dynamics, non-calcifiers competition, seasonality, and their response to upwelling/non-upwelling conditions.

We suggest that the contemporaneous coupling or decoupling of the different coccolithophore productivity proxies reflect changes in the carbon and carbonate system and conceived conceptual models of the carbon and carbonate cycles in the IbM (Fig. 7).

During the MIS 12 deglaciation all coccolithophore proxies show similar trends. This deglaciation is marked by clear rapid increases in $\mathrm{CP}$, NAR, and AlkAR, accompanied by a rapid, high-amplitude rise in SST, characteristic of terminations (e.g. Rodrigues et al., 2017). The increasing CP is linked to the growing influence and dominance of subtropical oligotrophic waters from the Azores and Iberian Poleward Currents (SST evidence) combined with a moderate to strong wind regime and consequent upwelling (Voelker et al., 2010). Based on paleoclimatic evidence, deglacial hinterland conditions in western Iberia and NW Africa were arid and resulted in increased (Saharan) dust flux (Desprat et al., 2007; Helmke et al., 2008; Hodell et al., 2013a, 2015; Rodrigues et al., 2011), which would supply high amounts of Fe and Si to the IbM. We suggest that this increased nutrient combination fertilized the non-calcifying phytoplankton component, namely diatoms (Duchamp-Alphonse et al., 2018; Helmke et al., 2008; Meckler et al., 2013; Rodrigues et al., 2011; Thomson et al., 2000), attributing to them a competitive advantage over coccolithophores, outcompeting them (e.g. Abrantes and Moita, 1999; Balch, 2004; Guerreiro et al., 2013). The combined increased surface productivity with both diatoms and coccolithophores blooming would likely allow for an increase in the soft-tissue pump into the deep ocean. During the deglaciation and early interglacial phases, the augmented (though only to intermediate levels) coccolithophore productivity was associated with higher calcification rates, and thus $\mathrm{CP}$, which resulted in a higher NAR. The higher $\mathrm{CaCO}_{3}$ production at the surface might have led to an increased $\mathrm{CaCO}_{3}$ and $\mathrm{C}_{\text {org }}$ export efficiency through the ballast effect of $\mathrm{CaCO}_{3}$ (e.g. Armstrong et al., 2001; Francois et al., 2002). This could explain the enhanced AlkAR as well as NAR at our study site for the deglaciations and early MIS 11c and MIS 9e, though with significantly different amplitudes.

During mid-interglacial MIS 11c and MIS 11b (410 to $390 \mathrm{kyr}$ ) and MIS 9e, all coccolithophore productivity proxies steadily increase, most likely associated with decreasing competition with diatoms for nutrients (see previous Discussion section). However the quite different AlkAR records for the deglaciation and early MIS 11c (428 to $410 \mathrm{kyr}$ ) in comparison with the rest of MIS $11 \mathrm{c}$ and MIS $11 \mathrm{~b}$ (410 kyr to $390 \mathrm{kyr}$ ) suggest a change in the phytoplanktonic community, favouring coccolithophores to the detriment of diatoms. We suggest that while diatoms were receiving a surplus replenishment of $\mathrm{Si}$ and $\mathrm{Fe}$ (as discussed in Sect. 5.1.2), the soft-tissue pump became more efficient because more organic particulate matter and particulate inorganic matter was present to form fast-sinking aggregates (Armstrong et al., 2001; Francois et al., 2002) allowing also for an increasing amount of alkenones to be exported and accumulated. We hypothesize that the timing of the rapid decrease in AlkAR could actually coincide with the decrease in the surface particulate organic matter as a consequence of the decreasing diatom productivity and surplus replenishment of $\mathrm{Si}$ and $\mathrm{Fe}$, which ceased by $410 \mathrm{ka}$, when AlkAR reach their minimum. This could have important implications for past $\mathrm{CO}_{2}$ fluxes from the atmosphere into the deep ocean, if indeed the softtissue pump increased its efficiency due to this combination of factors. 

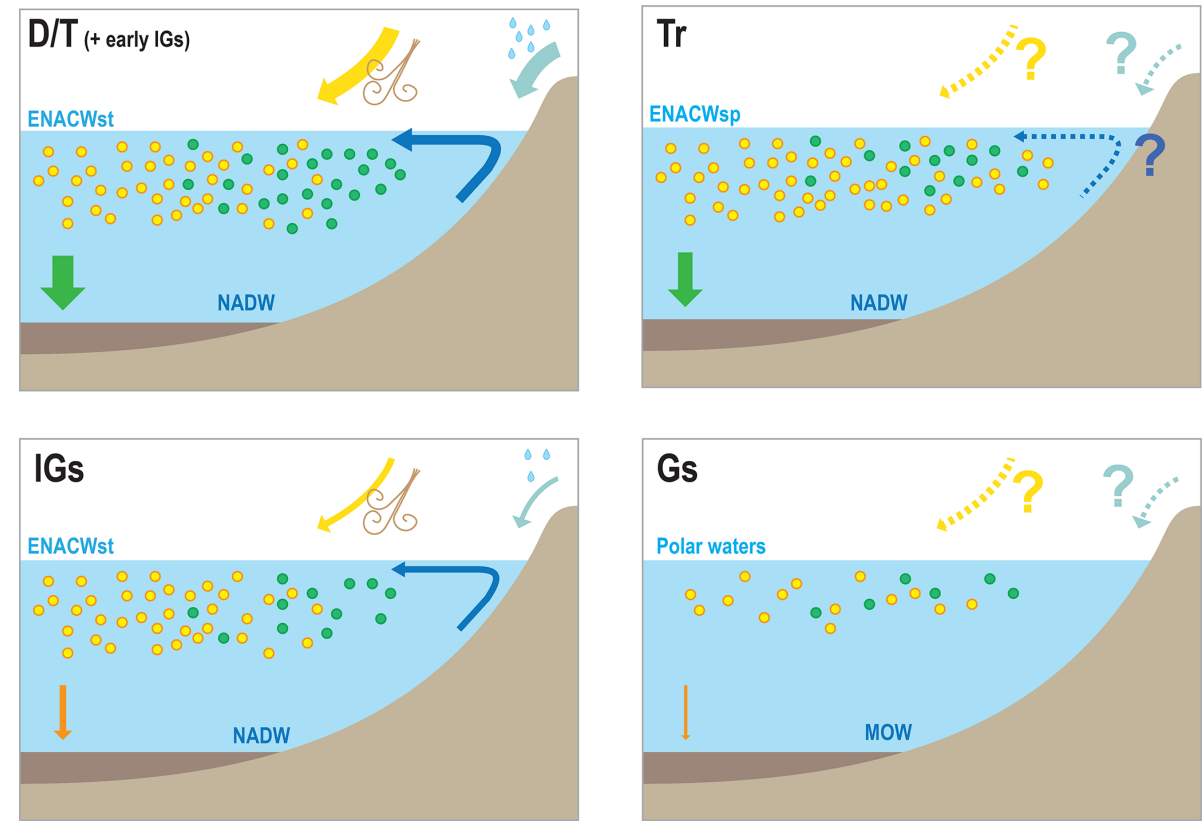

Figure 7. Conceptual models for the IbM of the different components of the carbon/carbonate cycle under different climatic scenarios: $\mathrm{D} / \mathrm{T}, \mathrm{Tr}$, IGs, and Gs stand for deglaciation/termination, transition from interglacial to glacial substages, interglacial substages, and glacial substages, respectively; ENACWst, ENACWsp, NADW, and MOW stand for Eastern North Atlantic Central Water of subtropical or subpolar origin, North Atlantic Deep Water, and Mediterranean Outflow Water, respectively. In the deglaciation scenario we depict increased surface productivity, associated with peaks of diatom and intermediate levels of coccolithophore productivity, and the largest marine snow export. Interglacial substages depict a decreased surplus of nutrients from terrigenous input, a decreased abundance of diatoms, and an intermediate levels of coccolithophore productivity due to the prevalence of ENACWst origin and a large decrease export; Transitions show a general increase in phytoplankton but placing more emphasis on coccolithophores because of the increasing and persistent predominance of ENACWsp origin, with intermediate levels of export. Glacial substages show a general decline in the phytoplankton associated with export minima and the increased influence of MOW.

From mid-MIS $11 \mathrm{c}$ to the end of MIS $11 \mathrm{~b}(410 \mathrm{ka}$ and until $390 \mathrm{ka}$ ), all coccolithophore productivity proxies increase, and we suggest that this coupled signal reflects that the coccolithophore productivity had a diminished competition with diatoms for nutrients and an associated less efficient softtissue pump in comparison with the deglaciation and early MIS 11c.

Based on the evidence from IODP Site U1313 in the open midlatitudinal North Atlantic (Cavaleiro et al., 2018), increases in coccolithophore calcification rate and productivity do not necessarily have to be a consequence of enhanced upwelling but can just as likely be related to the southward migration of the high-productivity/high-coccolithophorid belt (Cavaleiro et al., 2018; McIntyre et al., 1972; Villanueva et al., 2001). This band, currently located between 45 and $55^{\circ} \mathrm{N}$ (Antoine et al., 1996; Henson et al., 2009; Longhurst et al., 1995), is associated with the convergence zone between the subpolar and subtropical gyres (McIntyre et al., 1972). Along with the southward expansion of the subpolar gyre during periods of slowdown of the North Atlantic's thermohaline circulation (Alonso-Garcia et al., 2011; Rodrigues et al., 2017; Wright and Flower, 2002), the high-productivity band moved into the latitudes of the western IbM. So, the (gradual) dis- placement of this high-coccolithophorid belt could explain the rapid rise in CP productivity during MIS $11 \mathrm{~b}$ and associated maxima during MIS 11a, MIS 10c and MIS 9c when all three records - CP, NAR, and AlkAR - show contemporary increases (Fig. 6). Another factor affecting the signal preservation during the glacial periods and abrupt cold events of MIS $11 \mathrm{~b}$ to MIS 11a and of MIS 9d to MIS 9c could be shifts in the conditions prevailing at the sea floor. Whereas site MD03-2699 was bathed by NADW (North Atlantic Deep Water) when the North Atlantic's thermohaline circulation was strong, i.e. during the interglacial substages and the interstadials of MIS 11a, the North Atlantic Deep Water was replaced by Mediterranean Outflow Water (MOW) during times of a weak thermohaline circulation (stadials of MIS $11 \mathrm{~b}$ and MIS 11a; glacial MIS 12a and most of MIS 10) (Voelker and Lebreiro, 2010). Periods of MOW presence were associated with increased bottom current activity at site MD03-2699, especially during MIS 12a, when the winnowing of finer particles could have contributed to the low NAR and AlkAR (Fig. 6). On the other hand, the less oxygenated MOW would induce less $\mathrm{C}_{\text {org }}$ remineralization, which could have played a role in the AlkAR maxima occurring during late MIS 11a 

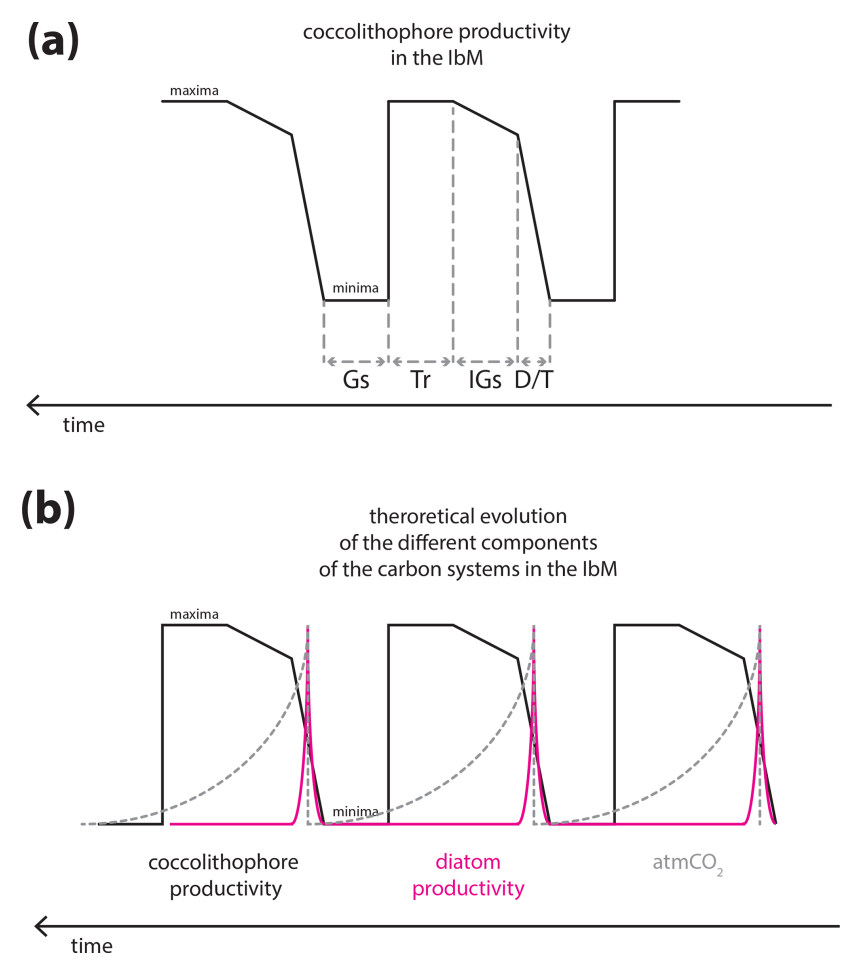

Figure 8. Theoretical curves of the carbon cycle components in the IbM: (a) hypothesized coccolithophore paleoproductivity for the IbM for the studied interval; (b) theoretical diatom productivity behaviour, with the characteristic spike at terminations (Meckler et al., 2013) and atmCO $\mathrm{CO}_{2}$ changes, with the characteristic sawtooth shape. Note that the intervals were drawn with no specific duration. Gs, Tr, IGs, and D/T stand for glacial substage, transition from interglacial to glacial substages, interglacial substages, and deglaciation/transition, respectively.

\subsection{Further research suggestions}

The CP reconstruction for the mid-Brunhes interval at site MD03-2699 yielded important findings but also raised issues that should be explored in the future. Extending this research into other interglacial substages could help disentangle the phytoplankton community response to upwelling intensity, namely if both diatoms and coccolithophores increase or if one decreases to the detriment of the other with changing upwelling intensities. This would offer further insights into the role of particulate organic vs. inorganic production in the surface ocean in an upwelling area such as the IbM. Further attention should also be given to the role of seasonality in CP and diatom productivity dynamics in the IbM, which could potentially be disentangled by using a direct land-sea correlation, namely evidence from pollen records. Given the discrepancy between our and other surface productivity and export estimations for glacial periods on the IbM (Abrantes, 1992; Salgueiro et al., 2010, 2014), it would be interesting to assess coccolithophore productivity in Late or early Pleis- tocene glacial stages to assess if our observation of low $\mathrm{CP}$ is restricted to mid-Brunhes conditions.

Additional research, specially incorporating the information gained into carbon and carbonate cycle models, could help to better predict the role of the IbM and other (eastern boundary) upwelling systems in glacial-interglacial atmCO $\mathrm{CO}_{2}$ changes. Did the coupled high productivity of non-calcifiers and calcifiers during deglaciations operate as sink of carbon or did the carbonate counter pump act to balance or even counteract the amplified soft-tissue pump?

Finally, Omta et al. (2013) presented a potential role of coccolithophores in the glacial-interglacial cycles of atmCO $\mathrm{C}_{2}$ and based their experiments on prey-predator models with the characteristic spiking predator (like coccolithophores) and a sawtooth-shaped curve of the prey behaviour (like alkalinity, which is positively and directly correlated to $\left.\left[\mathrm{CO}_{3}^{-2}\right]\right)$. Despite the undeniable direct link between calcifying phytoplankton and ocean alkalinity (e.g. Ridgwell and Zeebe, 2005), their model with the spikes of enhanced productivity at deglaciations/terminations actually resembles the non-calcifier behaviour in the IbM and off Africa, namely diatoms (Meckler et al., 2013; Thomson et al., 2000), more than that of coccolithophores, as our record shows. Coccolithophore productivity in the IbM margin seems to rise abruptly during the deglaciations, followed by a constant level or slight increase during the interglacial substages, and then steadily increases further during the progressive global cooling towards the glacial maximum only to then abruptly decrease under full glacial conditions (Fig. 7).

We hope that this information could be included in future modelling experiments, with both coccolithophore and diatom components of the dynamic phytoplanktonic community, to better describe the role of each functional group in the carbon and carbonate cycles in this upwelling system and with possible implications for other eastern boundary upwelling systems. We urge climate scientists to research the combined responses of the different components of the phytoplanktonic community, namely calcifiers and non-calcifiers. Much research has been conducted exploring only the productivity changes of one of these functional phytoplanktonic groups. Since the global ocean phytoplanktonic community with a potentially greater impact on atmCO fluxes is mostly composed of diatoms and coccolithophores in either the open ocean or upwelling areas, it is important to understand how the phytoplankton community dynamics have changed in the past.

\section{Conclusions}

In this study we applied the $\mathrm{CF} \mathrm{Sr} / \mathrm{Ca}$ ratio to reconstruct $\mathrm{CP}$ during the mid-Brunhes interval of MIS 9 to MIS 12 and discussed the different factors controlling CP in the western IbM. We found that the long-term coccolithophore productivity was primarily controlled by changes in the pale- 
oceanographic surface conditions, namely the origin of the predominant surface waters and their nutrient content. CP maxima were found during the transition from interglacial to glacial substages and associated with increasing presence of nutrient-richer transitional surface waters. The CP maxima during this transition were, however, frequently interrupted by abrupt decreases in CP linked to abrupt cooling events (HtEs) and a growing predominance of polar and subpolar surface waters, such as during glacial maximum substages. The deglaciations during early MIS 11c were marked by intermediate CP linked to the increased influence of subtropical, nutrient-poorer waters during winter, combined with increased terrigenous input of nutrients and moderate to strong upwelling during summer, conditions that are hypothesized to have an attributed to a competitive advantage of diatoms over coccolithophores.

Using a multiproxy approach and gathering $\mathrm{CP}$ (surface production signal) and AlkAR and NAR (bottom export and accumulation signals), we infer conceptual models of the carbon and carbonates cycles in the IbM during different periods and suggest future research questions to be tested through modelling. We hope that our new data can encourage Earth system modellers to look deeper into constraining the role of coccolithophores in the regional and global carbon and carbonate cycles, especially in the eastern boundary upwelling systems of the world.

Data availability. The data used will be available from the Pangaea data repository at https://doi.org/10.1594/PANGAEA.908192

Author contributions. $\mathrm{CC}$ and $\mathrm{AV}$ designed the study. CC prepared the samples and analysed them under the supervision of HS. CC drafted the paper, and all authors contributed to the discussion and to the final version.

Competing interests. The authors declare that they have no conflict of interest.

Acknowledgements. Catarina Cavaleiro would like to thank the laboratorial and analytical support at the Geosciences Department, University of Oviedo, and at MARUM and Geosciences Department, University of Bremen. Catarina Cavaleiro further acknowledges the effort and valuable help of Ana Méndez-Vicente while measuring the coccolith fraction samples at the University of Oviedo. also thanks Dulce Oliveira, Fátima Abrantes, Filipa Naughton, and Teresa Rodrigues for the helpful comments on the paper. We thank Tom Dunkley Jones and Michaël Hermoso for their constructive reviews that greatly improved the paper.
Financial support. This research has been supported by the Fundação para a Ciência e a Tecnologia (grant nos. PORTO (PDCT/MAR/58282/2004), INTER-TRACE (PTDC/CLI/70772/2006), CCMAR (UID/Multi/04326/2019), doctoral fellowship (SFRH/BD/84187/2012), and investigator contract (IF/01500/2014)).

The article processing charges for this open-access publication were covered by the University of Bremen.

Review statement. This paper was edited by Luc Beaufort and reviewed by Tom Dunkley Jones and Michaël Hermoso.

\section{References}

Abrantes, F.: Palaeoproductivity oscillations during the last $130 \mathrm{ka}$ along the Portuguese and NW African margins, Geol. Soc. London, Spec. Publ., 64, 499-510, https://doi.org/10.1144/GSL.SP.1992.064.01.32, 1992.

Abrantes, F.: $200000 \mathrm{yr}$ diatom records from Atlantic upwelling sites reveal maximum productivity during LGM and a shift in phytoplankton community structure at $185 ? 000 \mathrm{yr}$, Earth Planet. Sci. Lett., 176, 7-16, https://doi.org/10.1016/S0012821X(99)00312-X, 2000.

Abrantes, F. and Moita, M. T.: Water column and recent sediment data on diatoms and coccolithophorids, off Portugal, confirm sediment record of upwelling events, Oceanol. Acta, 22, 319336, https://doi.org/10.1016/S0399-1784(99)80055-3, 1999.

Abrantes, F., Rodrigues, T., Ventura, C., Santos, C., Li, B., Kim, J. K., Roehl, U., Voelker, A., and Hodell, D.: Past Productivity conditions off SW Iberia at the transition from the $41 \mathrm{ky}$ to the $100 \mathrm{ky}$ world; The record of IODP Sites U1385 and U1391, in Achievements and perspectives in scientific ocean and continental drilling - EGU, 2017.

Alonso-Garcia, M., Sierro, F. J., and Flores, J. A.: Arctic front shifts in the subpolar North Atlantic during the MidPleistocene (800-400 ka) and their implications for ocean circulation, Palaeogeogr. Palaeoclim. Palaeoecol., 311, 268-280, https://doi.org/10.1016/j.palaeo.2011.09.004, 2011.

Álvarez-salgado, X. A., Castro, C. G., Pérez, F. F., and Fraga, F.: Nutrient mineralization patterns in shelf waters of the Western Iberian upwelling, Cont. Shelf Res., 17, 1247-1270, https://doi.org/10.1016/S0278-4343(97)00014-9, 1997.

Alvarez, I., Gomez-Gesteira, M., deCastro, M., and Dias, J. M.: Spatiotemporal evolution of upwelling regime along the western coast of the Iberian Peninsula, J. Geophys. Res.-Ocean., 113, C07020, https://doi.org/10.1029/2008JC004744, 2008.

Alvarez, I., Gomez-Gesteira, M., deCastro, M., Lorenzo, M. N., Crespo, A. J. C., and Dias, J. M.: Comparative analysis of upwelling influence between the western and northern coast of the Iberian Peninsula, Cont. Shelf Res., 31, 388-399, https://doi.org/10.1016/j.csr.2010.07.009, 2011.

Amore, F. O., Flores, J. A., Voelker, A. H. L., Lebreiro, S. M., Palumbo, E., and Sierro, F. J.: A Middle Pleistocene Northeast Atlantic coccolithophore record: Paleoclimatology and paleoproductivity aspects, Mar. Micropaleontol., 90, 44-59, https://doi.org/10.1016/j.marmicro.2012.03.006, 2012. 
Andrews, J. T. and Voelker, A. H. L.: "Heinrich events" (\& sediments): A history of terminology and recommendations for future usage, Quat. Sci. Rev., 187, 31-40, https://doi.org/10.1016/j.quascirev.2018.03.017, 2018.

Antoine, D., André, J.-M., and Morel, A.: Oceanic primary production: 2. Estimation at global scale from satellite (Coastal Zone Color Scanner) chlorophyll, Global Biogeochem. Cy., 10, 57-69, https://doi.org/10.1029/95GB02832, 1996.

Archer, D. and Maier-Reimer, E.: Effect of deep-sea sedimentary calcite preservation on atmospheric $\mathrm{CO}_{2}$ concentration, Nature, 367, 260-263, https://doi.org/10.1038/367260a0, 1994.

Archer, D., Winguth, A., Lea, D., and Mahowald, N.: What caused the glacial/interglacial atmospheric $p \mathrm{CO}_{2}$ cycles?, Rev. Geophys., 38, 159-189, https://doi.org/10.1029/1999RG000066, 2000.

Arístegui, J., Barton, E. D., Álvarez-Salgado, X. A., Santos, A. M. P., Figueiras, F. G., Kifani, S., Hernández-León, S., Mason, E., Machú, E., and Demarcq, H.: Sub-regional ecosystem variability in the Canary Current upwelling, Prog. Oceanogr., 83, 33-48, https://doi.org/10.1016/j.pocean.2009.07.031, 2009.

Armstrong, R. A., Lee, C., Hedges, J. I., Honjo, S., and Wakeham, S. G.: A new, mechanistic model for organic carbon fluxes in the ocean based on the quantitative association of POC with ballast minerals, Deep-Sea Res. Pt. II., 49, 219-236, https://doi.org/10.1016/S0967-0645(01)00101-1, 2001.

Ausín, B., Zúñiga, D., Flores, J. A., Cavaleiro, C., Froján, M., Villacieros-robineau, N., Alonso-pérez, F., Arbones, B., Santos, C., Granda, F. De, Castro, C. G., Abrantes, F., Eglinton, T. I., and Salgueiro, E.: Spatial and temporal variability in coccolithophore abundance and distribution in the NW Iberian coastal upwelling system, 245-262, 2018.

Balch, W., Fritz, J., and Fernandez, E.: Decoupling of calcification and photosynthesis in the coccolithophore Emiliania huxleyi under steady-state light-limited growth, Mar. Ecol. Prog. Ser., 142, 87-97, https://doi.org/10.3354/meps142087, 1996.

Balch, W. M.: Re-evaluation of the physiological ecology of coccolithophores BT - Coccolithophores: From Molecular Processes to Global Impact, edited by: Thierstein, H. R. and Young, J. R., Springer Berlin Heidelberg, Berlin, Heidelberg, 165-190, 2004.

Balch, W. M.: The Ecology, Biogeochemistry, and Optical Properties of Coccolithophores, Ann. Rev. Mar. Sci., 10, 71-98, https://doi.org/10.1146/annurev-marine-121916-063319, 2018.

Barker, S., Archer, D., Booth, L., Elderfield, H., Henderiks, J., and Rickaby, R. E. M.: Globally increased pelagic carbonate production during the Mid-Brunhes dissolution interval and the $\left(\mathrm{CO}_{2}\right)$ paradox of (MIS) ceright 11, Quat. Sci. Rev., 25, 3278-3293, https://doi.org/10.1016/j.quascirev.2006.07.018, 2006.

Barton, E. D.: Canary and Portugal Currents, in: Encyclopedia of Ocean Sciences, edited by: Steele, J., Academic Press, Oxford, 467-476, 2001.

Baumann, K.-H. and Freitag, T.: Pleistocene fluctuations in the northern Benguela Current system as revealed by coccolith assemblages, Mar. Micropaleontol., 52, 195-215, https://doi.org/10.1016/j.marmicro.2004.04.011, 2004.

Baumann, K.-H., Andruleit, H., and Samtleben, C.: Coccolithophores in the Nordic Seas: comparison of living communities with surface sediment assemblages, Deep-Sea Res. Pt. II, 47, 1743-1772, https://doi.org/10.1016/s0967-0645(00)000059, 2000.
Baumann, K.-H., Andruleit, H., Böckel, B., Geisen, M., and Kinkel, H.: The significance of extant coccolithophores as indicators of ocean water masses, surface water temperature, and palaeoproductivity: a review, Paläontologische Z., 79, 93-112, https://doi.org/10.1007/BF03021756, 2005.

Beaufort, L., Lancelot, Y., Camberlin, P., Cayre, O., Vincent, E., Bassinot, F., and Labeyrie, L.: Insolation cycles as a mojor control of equatorial Indian Ocean primary production, Science, 278, 1451-1454, 1997.

Beaufort, L., de Garidel-Thoron, T., Mix, A. C., and Pisias, N. G.: ENSO-like Forcing on Oceanic Primary Production During the Late Pleistocene, Science, 80, 293, 2440-2444, https://doi.org/10.1126/science.293.5539.2440, 2001.

Berger, A.: Milankovitch Theory and climate, Rev. Geophys., 26, 624-657, https://doi.org/10.1029/RG026i004p00624, 1988.

Berger, A., Crucifix, M., Hodell, D., and PAGES, P. I. W. G. of: Interglacials of the last 800,000 years, Rev. Geophys., 54, 162219, https://doi.org/10.1002/2015RG000482, 2015.

Berger, W. H.: Increase of carbon dioxide in the atmosphere during deglaciation: the coral reef hypothesis, Naturwissenschaften, 69, 87-88, https://doi.org/10.1007/BF00441228, 1982.

Bischof, B., Mariano, A. J., and Ryan, H. E.: The Portugal Current System, Ocean Surf. Curr., https://oceancurrents.rsmas.miami. edu/atlantic/por (last access: July 2018), 2003.

Blain, S., Guieu, C., Claustre, H., Leblanc, K., Moutin, T., Quèguiner, B., Ras, J., and Sarthou, G.: Availability of iron and major nutrients for phytoplankton in the northeast Atlantic Ocean, Limnol. Oceanogr., 49, 2095-2104, https://doi.org/10.4319/lo.2004.49.6.2095, 2004.

Bollmann, J., Baumann, K.-H., and Thierstein, H. R.: Global dominance of Gephyrocapsa coccoliths in the Late Pleistocene: Selective dissolution, evolution, or global environmental change?, Paleoceanography, 13, 517-529, https://doi.org/10.1029/98PA00610, 1998.

Bozzano, G., Kuhlmann, H., and Alonso, B.: Storminess control over African dust input to the Moroccan Atlantic margin (NW Africa) at the time of maxima boreal summer insolation: a record of the last $220 \mathrm{kyr}$, Palaeogeogr. Palaeoclim. Palaeoecol., 183, 155-168, https://doi.org/10.1016/S0031-0182(01)00466-7, 2002.

Brady, R. X., Lovenduski, N. S., Alexander, M. A., Jacox, M., and Gruber, N.: On the role of climate modes in modulating the airsea $\mathrm{CO}_{2}$ fluxes in eastern boundary upwelling systems, Biogeosciences, 16, 329-346, https://doi.org/10.5194/bg-16-329-2019, 2019.

Broccoli, A. J., Dahl, K. A., and Stouffer, R. J.: Response of the ITCZ to Northern Hemisphere cooling, Geophys. Res. Lett., 33, L01702, https://doi.org/10.1029/2005GL024546, 2006.

Broecker, W. S. and Peng, T.-H.: The role of $\mathrm{CaCO}_{3}$ compensation in the glacial to interglacial atmospheric $\mathrm{CO}_{2}$ change, Global Biogeochem. Cy., 1, 15-29, https://doi.org/10.1029/GB001i001p00015, 1987.

Cabeçadas, G. and Brogueira, M. J.: Sediments in a Portuguese coastal area \&\#8212; pool sizes of mobile and immobile forms of nitrogen and phosphorus, Mar. Freshw. Res., 48, 559-563, https://doi.org/10.1071/MF96053, 1998.

Cachão, M., Oliveira, A., and Vitorino, J.: Subtropical winter guests, offshore Portugal, J. Nannoplankt. Res., 22, 19-26, 2000. 
Candy, I., Schreve, D. C., Sherriff, J., and Tye, G. J.: Marine Isotope Stage 11: Palaeoclimates, palaeoenvironments and its role as an analogue for the current interglacial, Earth-Sci. Rev., 128, 18-51, https://doi.org/10.1016/j.earscirev.2013.09.006, 2014.

Capellacci, S., Battocchi, C., Casabianca, S., Giovine, M., Bavestrello, G., and Penna, A.: Bioavailability of different chemical forms of dissolved silica can affect marine diatom growth, Mar. Ecol., 34, 103-111, https://doi.org/10.1111/j.14390485.2012.00529.x, 2013.

Cavaleiro, C., Voelker, A. H. L., Stoll, H., Baumann, K. H., Kulhanek, D. K., Naafs, B. D. A., Stein, R., Grützner, J., Ventura, C., and Kucera, M.: Insolation forcing of coccolithophore productivity in the North Atlantic during the Middle Pleistocene, Quat. Sci. Rev., 191, 318-336, https://doi.org/10.1016/j.quascirev.2018.05.027, 2018.

Cermeño, P., Lee, J.-B., Wyman, K., and Schofield, O.: Competitive dynamics in two species of marine phytoplankton under non-equilibrium conditions, Mar. Ecol. Prog. Ser., 429, 19-28, 2011

Daniels, C. J., Poulton, A. J., Balch, W. M., Marañón, E., Adey, T., Bowler, B. C., Cermeño, P., Charalampopoulou, A., Crawford, D. W., Drapeau, D., Feng, Y., Fernández, A., Fernández, E., Fragoso, G. M., González, N., Graziano, L. M., Heslop, R., Holligan, P. M., Hopkins, J., Huete-Ortega, M., Hutchins, D. A., Lam, P. J., Lipsen, M. S., López-Sandoval, D. C., Loucaides, S., Marchetti, A., Mayers, K. M. J., Rees, A. P., Sobrino, C., Tynan, E., and Tyrrell, T.: A global compilation of coccolithophore calcification rates, Earth Syst. Sci. Data, 10, 18591876, https://doi.org/10.5194/essd-10-1859-2018, 2018.

de Abreu, L., Abrantes, F. F., Shackleton, N. J., Tzedakis, P. C., McManus, J. F., Oppo, D. W., and Hall, M. A.: Ocean climate variability in the eastern North Atlantic during interglacial marine isotope stage 11: A partial analogue to the Holocene?, Paleoceanography, 20, 1-15, https://doi.org/10.1029/2004PA001091, 2005.

Desprat, S., Sánchez Goñi, M. F., Naughton, F., Turon, J. L., Duprat, J., Malaizé, B., Cortijo, E., and Peypouquet, J. P.: 25. Climate variability of the last five isotopic interglacials: Direct land-seaice correlation from the multiproxy analysis of North-Western Iberian margin deep-sea cores, Dev. Quat. Sci., 7, 375-386, https://doi.org/10.1016/S1571-0866(07)80050-9, 2007.

Desprat, S., Sánchez Goñi, M. F., McManus, J. F., Duprat, J., and Cortijo, E.: Millennial-scale climatic variability between 340000 and 270000 years ago in SW Europe: evidence from a NW Iberian margin pollen sequence, Clim. Past, 5, 53-72, https://doi.org/10.5194/cp-5-53-2009, 2009.

Desprat, S., Oliveira, D., Naughton, F., and Sánchez Goñi, M. F.: L'étude du pollen des séquences sédimentaires marines pour la compréhension du climat?: l'exemple des périodes chaudes passées, Quaternaire, 28, 259-269, https://doi.org/10.4000/quaternaire.8102, 2017.

de Villiers, S., Greaves, M., and Elderfield, H.: An intensity ratio calibration method for the accurate determination of $\mathrm{Mg} / \mathrm{Ca}$ and $\mathrm{Sr} / \mathrm{Ca}$ of marine carbonates by ICPAES, Geochem., Geophys. Geosyst., 3, 2001GC000169, https://doi.org/10.1029/2001GC000169, 2002.

Duchamp-Alphonse, S., Siani, G., Michel, E., Beaufort, L., Gally, Y., and Jaccard, S. L.: Enhanced ocean-atmosphere carbon partitioning via the carbonate counter pump during the last deglacial,
Nat. Commun., 9, 2396, https://doi.org/10.1038/s41467-01804625-7, 2018.

Figueiras, F. G., Labarta, U., and Fernández Reiriz, M. J.: Coastal upwelling, primary production and mussel growth in the Rías Baixas of Galicia, Hydrobiologia, 484, 121-131, https://doi.org/10.1023/A:1021309222459, 2002.

Fink, C., Baumann, K.-H., Groeneveld, J., and Steinke, S.: Strontium/Calcium ratio, carbon and oxygen stable isotopes in coccolith carbonate from different grain-size fractions in South Atlantic surface sediments, Geobios, 43, 151-164, https://doi.org/10.1016/j.geobios.2009.11.001, 2010.

Fiúza, A. F. D., de Macedo, M. E., and Guerreiro, M. R.: Climatological space and time-variation of the portuguese coastal upwelling, Oceanol. Acta, 5, 31-40, 1982.

Fiúza, A. F. G.: Upwelling Patterns off Portugal BT - Coastal Upwelling Its Sediment Record: Part A: Responses of the Sedimentary Regime to Present Coastal Upwelling, edited by: Suess, E. and Thiede, J., Springer US, Boston, MA, 85-98, 1983.

Fiúza, A. F. G., Hamann, M., Ambar, I., Diaz del Rı, G., González, N., and Cabanas, J. M.: Water masses and their circulation off western Iberia during May 1993, Deep-Sea Res. Pt. I, 45, 1127 1160, https://doi.org/10.1016/S0967-0637(98)00008-9, 1998.

Flores, J.-A. and Sierro, F. J.: PALEOCEANOGRAPHY, BIOLOGICAL PROXIES Coccoliths, in: Encyclopedia of Quaternary Science, edited by: Elias, S. A., Elsevier, Oxford, 1634-1646, 2007.

Flores, J. A., Sierro, F. J., Francés, G., Vázquez, A., and Zamarren o, I.: The last 100,000 years in the western Mediterranean: sea surface water and frontal dynamics as revealed by coccolithophores, Mar. Micropaleontol., 29, 351-366, https://doi.org/10.1016/S0377-8398(96)00029-1, 1997.

Fraga, F.: Upwelling off the Galician Coast, Northwest Spain, Coast. Upwelling, https://doi.org/10.1029/CO001p0176, 1981.

Francois, R., Honjo, S., Krishfield, R., and Manganini, S.: Factors controlling the flux of organic carbon to the bathypelagic zone of the ocean, Global Biogeochem. Cy., 16, 34-1-34-20, https://doi.org/10.1029/2001GB001722, 2002.

Guerreiro, C., Oliveira, A., De Stigter, H., Cachão, M., Sá, C., Borges, C., Cros, L., Santos, A., Fortuño, J. M., and Rodrigues, A.: Late winter coccolithophore bloom off central Portugal in response to river discharge and upwelling, Cont. Shelf Res., 59, 65-83, https://doi.org/10.1016/j.csr.2013.04.016, 2013.

Haynes, R. and Barton, E. D.: A poleward flow along the Atlantic coast of the Iberian peninsula, J. Geophys. Res.-Oceans, 95, 11425-11441, https://doi.org/10.1029/JC095iC07p11425, 2018.

Helmke, J. P., Bauch, H. A., Röhl, U., and Kandiano, E. S.: Uniform climate development between the subtropical and subpolar Northeast Atlantic across marine isotope stage 11, Clim. Past, 4, 181-190, https://doi.org/10.5194/cp-4-181-2008, 2008.

Hemming, S. R.: Heinrich events: Massive late Pleistocene detritus layers of the North Atlantic and their global climate imprint, Rev. Geophys., 42, RG1005, https://doi.org/10.1029/2003RG000128, 2004.

Henson, S. A., Dunne, J. P., and Sarmiento, J. L.: Decadal variability in North Atlantic phytoplankton blooms, J. Geophys. Res., 114, C04013, https://doi.org/10.1029/2008JC005139, 2009.

Hernández-Almeida, I., Ausín, B., Saavedra-Pellitero, M., Baumann, K.-H., and Stoll, H. M.: Quantitative reconstruction of primary productivity in low latitudes during the last glacial maximum and the mid-to-late Holocene from a global Florisphaera 
profunda calibration dataset, Quat. Sci. Rev., 205, 166-181, https://doi.org/10.1016/j.quascirev.2018.12.016, 2019.

Hodell, D., Crowhurst, S., Skinner, L., Tzedakis, P. C., Margari, V., Channell, J. E. T., Kamenov, G., MacLachlan, S., and Rothwell, G.: Response of Iberian Margin sediments to orbital and suborbital forcing over the past $420 \mathrm{ka}$, Paleoceanography, 28, 185-199, https://doi.org/10.1002/palo.20017, 2013a.

Hodell, D. A., Lourens, L., Stow, D. A. V., Hernández-Molina, J., Alvarez Zarikian, C. A., Abrantes, F., Acton, G. D., Bahr, A., Balestra, B., Llave Barranco, E., Carrara, G., Crowhurst, S., Ducassou, E., Flood, R. D., Flores, J. A., Furota, S., Grimalt, J., Grunert, P., Jimenez-Espejo, F. J., Kyoung Kim, J., Konijnendijk, T., Krissek, L. A., Kuroda, J., Li, B., Lofi, J., Margari, V., Martrat, B., Miller, M. D., Nanayama, F., Nishida, N., Richter, C., Rodrigues, T., Rodríguez-Tovar, F. J., Freixo Roque, A. C., Sanchez Goni, M. F., Sierro Sánchez, F. J., Singh, A. D., Skinner, L., Sloss, C. R., Takashimizu, Y., Tjallingii, R., Tzanova, A., Tzedakis, C., Voelker, A., Xuan, C., and Williams, T.: The "Shackleton Site" (IODP Site U1385) on the Iberian Margin, Sci. Drill., 16, 13-19, https://doi.org/10.5194/sd-16-13-2013, 2013 b.

Hodell, D., Lourens, L., Crowhurst, S., Konijnendijk, T., Tjallingii, R., Jiménez-Espejo, F., Skinner, L., Tzedakis, P. C., Abrantes, F., Acton, G. D., Alvarez Zarikian, C. A., Bahr, A., Balestra, B., Barranco, E. L., Carrara, G., Ducassou, E., Flood, R. D., Flores, J.-A., Furota, S., Grimalt, J., Grunert, P., HernándezMolina, J., Kim, J. K., Krissek, L. A., Kuroda, J., Li, B., Lofi, J., Margari, V., Martrat, B., Miller, M. D., Nanayama, F., Nishida, N., Richter, C., Rodrigues, T., Rodríguez-Tovar, F. J., Roque, A. C. F., Sanchez Goñi, M. F., Sierro Sánchez, F. J., Singh, A. D., Sloss, C. R., Stow, D. A. V, Takashimizu, Y., Tzanova, A., Voelker, A., Xuan, C., and Williams, T.: A reference time scale for Site U1385 (Shackleton Site) on the SW Iberian Margin, Global Planet. Change, 133, 49-64, https://doi.org/10.1016/j.gloplacha.2015.07.002, 2015.

Hodell, D. A. and Channell, J. E. T.: Mode transitions in Northern Hemisphere glaciation: co-evolution of millennial and orbital variability in Quaternary climate, Clim. Past, 12, 1805-1828, https://doi.org/10.5194/cp-12-1805-2016, 2016.

Hodell, D. A. and Curtis, J. H.: Oxygen and carbon isotopes of detrital carbonate in North Atlantic Heinrich Events, Mar. Geol., 256, 30-35, https://doi.org/10.1016/j.margeo.2008.09.010, 2008.

Hodell, D. A., Channeil, J. E. T., Curtis, J. H., Romero, O. E., and Röhl, U.: Onset of "Hudson Strait" Heinrich events in the eastern North Atlantic at the end of the middle Pleistocene transition $(\sim 640 \mathrm{ka})$ ?, Paleoceanography, 23, 1-16, https://doi.org/10.1029/2008PA001591, 2008.

Hodell, D. A., Nicholl, J. A., Bontognali, T. R. R., Danino, S., Dorador, J., Dowdeswell, J. A., Einsle, J., Kuhlmann, H., Martrat, B., Mleneck-Vautravers, M. J., Rodríguez-Tovar, F. J., and Röhl, U.: Anatomy of Heinrich Layer 1 and its role in the last deglaciation, Paleoceanography, 32, 284-303, https://doi.org/10.1002/2016PA003028, 2017.

Hopkins, J., Henson, S. A., Painter, S. C., Tyrrell, T., and Poulton, A. J.: Phenological characteristics of global coccolithophore blooms, Global Biogeochem. Cy., 29, 239-253, https://doi.org/10.1002/2014GB004919, 2015.

Hostetler, S. W., Clark, P. U., Bartlein, P. J., Mix, A. C., and Pisias, N. J.: Atmospheric transmission of North Atlantic
Heinrich events, J. Geophys. Res.- Atmos., 104, 3947-3952, https://doi.org/10.1029/1998JD200067, 1999.

Jansen, J. H. F., Kuijpers, A., and Troelstra, S. R.: A MidBrunhes Climatic Event: Long-Term Changes in Global Atmosphere and Ocean Circulation, Science, 232, 619-622, https://doi.org/10.1126/science.232.4750.619, 1986.

Lawton, J. H., Marotzke, J., Marsh, R., McCave, I. N., Barker, S., Higgins, J. A., and Elderfield, H.: The future of the carbon cycle: review, calcification response, ballast and feedback on atmospheric $\mathrm{CO}_{2}$, Philos. T. Roy. Soc. A, 361, 1977-1999, https://doi.org/10.1098/rsta.2003.1238, 2003.

Lebreiro, S. M., Voelker, A. H. L., Vizcaino, A., Abrantes, F. G., Alt-Epping, U., Jung, S., Thouveny, N., and Gràcia, E.: Sediment instability on the Portuguese continental margin under abrupt glacial climate changes (last 60 kyr), Quat. Sci. Rev., 28, 32113223, https://doi.org/10.1016/j.quascirev.2009.08.007, 2009.

Lionello, P., Malanotte-Rizzoli, P., Boscolo, R., Alpert, P., Artale, V., Li, L., Luterbacher, J., May, W., Trigo, R., Tsimplis, M., Ulbrich, U., and Xoplaki, E.: The Mediterranean climate: An overview of the main characteristics and issues, 1-26, 2006.

Lisiecki, L. E. and Raymo, M. E.: A Pliocene-Pleistocene stack of 57 globally distributed benthic $\delta^{18} \mathrm{O}$ records, Paleoceanography, 20, PA1003, https://doi.org/10.1029/2004PA001071, 2005.

Longhurst, A., Sathyendranath, S., Platt, T., and Caverhill, C.: An estimate of global primary production in the ocean from satellite radiometer data, J. Plankton Res., 17, 1245-1271, https://doi.org/10.1093/plankt/17.6.1245, 1995.

Loutre, M. F. and Berger, A.: Marine Isotope Stage 11 as an analogue for the present interglacial, Global Planet. Change, 36, 209-217, https://doi.org/10.1016/S0921-8181(02)00186-8, 2003.

Lüthi, D., Le Floch, M., Bereiter, B., Blunier, T., Barnola, J.-M., Siegenthaler, U., Raynaud, D., Jouzel, J., Fischer, H., Kawamura, K., and Stocker, T. F.: High-resolution carbon dioxide concentration record 650,000-800,000 years before present, Nature, 453, 379-382, https://doi.org/10.1038/nature06949, 2008.

Maiorano, P., Marino, M., Balestra, B., Flores, J.-A., Hodell, D. A., and Rodrigues, T.: Coccolithophore variability from the Shackleton Site (IODP Site U1385) through MIS 16-10, Global Planet. Change, 133, 35-48, https://doi.org/10.1016/j.gloplacha.2015.07.009, 2015.

Marino, M., Maiorano, P., and Flower, B. P.: Calcareous nannofossil changes during the Mid-Pleistocene Revolution: Paleoecologic and paleoceanographic evidence from North Atlantic Site 980/981, Palaeogeogr. Palaeoclim. Palaeoecol., 306, 58-69, https://doi.org/10.1016/j.palaeo.2011.03.028, 2011.

Marino, M., Maiorano, P., Tarantino, F., Voelker, A., Capotondi, L., Girone, A., Lirer, F., Flores, J. A., and Naafs, B. D. A.: Coccolithophores as proxy of seawater changes at orbital-to-millennial scale during middle Pleistocene Marine Isotope Stages 14-9 in North Atlantic core MD01-2446, Paleoceanography, 29, 518532, https://doi.org/10.1002/2013PA002574, 2014.

Martin, J. H., Gordon, R. M., and Fitzwater, S. E.: Iron in Antarctic waters, Nature, 345, 156-158, https://doi.org/10.1038/345156a0, 1990.

Martrat, B., Grimalt, J. O., Shackleton, N. J., de Abreu, L., Hutterli, M. A., Stocker, T. F., and Abreu, L. de: Four Climate Cycles of Recurring Deep and Surface Water Desta- 
bilizations non the Iberian Margin, Science, 317, 502-506, https://doi.org/10.1126/science.1139994, 2007.

Mason, E., Coombs, S. H., and Oliveira, P. B.: An overview of the literature concerning the oceanography of the eastern North Atlantic region. Relatórios Científicos e Técnicos IPIMAR Série Digital, 33, p 59, 2005.

McClelland, H. L. O., Barbarin, N., Beaufort, L., Hermoso, M., Ferretti, P., Greaves, M., and Rickaby, R. E. M.: Calcification response of a key phytoplankton family to millennial-scale environmental change, Sci. Rep., 6, 1-11, https://doi.org/10.1038/srep34263, 2016.

McIntyre, A. and Bé, A. W. H.: Modern coccolithophoridae of the atlantic ocean-I. Placoliths and cyrtoliths, Deep-Sea Res., 14, 561-597, https://doi.org/10.1016/0011-7471(67)90065-4, 1967.

McIntyre, A. and Molfino, B.: Forcing of Atlantic Equatorial and Subpolar Millennial Cycles by Precession, Science, 274, 18671870, https://doi.org/10.1126/science.274.5294.1867, 1996.

McIntyre, A., Ruddiman, W. F., and Jantzen, R.: Southward penetrations of the North Atlantic polar front: faunal and floral evidence of large-scale surface water mass movements over the last 225,000 years, Deep-Sea Res., 19, 61-77, https://doi.org/10.1016/0011-7471(72)90073-3, 1972.

McManus, J. F., Oppo, D. W., and Cullen, J. L.: A 0.5million-year record of millenial-scale climate variability in the North Atlantic, Science, 283, 971-975, https://doi.org/10.1126/science.283.5404.971, 1999.

Meckler, A. N., Sigman, D. M., Gibson, K. A., François, R., Martínez-García, A., Jaccard, S. L., Röhl, U., Peterson, L. C., Tiedemann, R., and Haug, G. H.: Deglacial pulses of deep-ocean silicate into the subtropical North Atlantic Ocean, Nature, 495, 495-498, https://doi.org/10.1038/nature12006, 2013.

Mejía, L. M., Ziveri, P., Cagnetti, M., Bolton, C., Zahn, R., Marino, G., Martínez-Méndez, G., and Stoll, H.: Effects of midlatitude westerlies on the paleoproductivity at the Agulhas Bank slope during the penultimate glacial cycle: Evidence from coccolith $\mathrm{Sr} / \mathrm{Ca}$ ratios, Paleoceanography, 29, 697-714, https://doi.org/10.1002/2013PA002589, 2014.

Merico, A., Tyrrell, T., Lessard, E. J., Oguz, T., Stabeno, P. J., Zeeman, S. I., and Whitledge, T. E.: Modelling phytoplankton succession on the Bering Sea shelf: role of climate influences and trophic interactions in generating Emiliania huxleyi blooms 1997-2000, Deep-Sea Res. Pt. I, 51, 1803-1826, https://doi.org/10.1016/j.dsr.2004.07.003, 2004.

Meyers, S. R.: Astrochron: An R Package for Astrochronology, Astrochron An R Packag, Astrochronology, 1-132, 2014.

Moita, M. T.: Estrutura, variabilidade e dinâmica do Fitoplâncton na Costa de Portugal Continental, 1-219, 2001.

Müller, M. N., Lebrato, M., Riebesell, U., Barcelos e Ramos, J., Schulz, K. G., Blanco-Ameijeiras, S., Sett, S., Eisenhauer, A., and Stoll, H. M.: Influence of temperature and $\mathrm{CO}_{2}$ on the strontium and magnesium composition of coccolithophore calcite, Biogeosciences, 11, 1065-1075, https://doi.org/10.5194/bg-111065-2014, 2014.

Oliveira, D., Desprat, S., Rodrigues, T., Naughton, F., Hodell, D., Trigo, R., Rufino, M., Lopes, C., Abrantes, F., and Sánchez Goñi, M. F.: The complexity of millennial-scale variability in southwestern Europe during MIS 11, Quat. Res., 86, 373-387, https://doi.org/10.1016/j.yqres.2016.09.002, 2016.
Oliveira, D., Sánchez Goñi, M. F., Naughton, F., PolancoMartínez, J. M., Jimenez-Espejo, F. J., Grimalt, J. O., Martrat, B., Voelker, A. H. L., Trigo, R., Hodell, D., Abrantes, F., and Desprat, S.: Unexpected weak seasonal climate in the western Mediterranean region during MIS 31, a highinsolation forced interglacial, Quat. Sci. Rev., 161, 1-17, https://doi.org/10.1016/j.quascirev.2017.02.013, 2017.

Oliveira, D., Desprat, S., Yin, Q., Naughton, F., Trigo, R., Rodrigues, T., Abrantes, F., and Sánchez Goñi, M. F.: Unraveling the forcings controlling the vegetation and climate of the best orbital analogues for the present interglacial in SW Europe, Clim. Dynam, 51, 667-686, https://doi.org/10.1007/s00382-017-39487, 2018.

Omta, A. W., van Voorn, G. A. K., Rickaby, R. E. M., and Follows, M. J.: On the potential role of marine calcifiers in glacialinterglacial dynamics, Global Biogeochem. Cy., 27, 692-704, https://doi.org/10.1002/gbc.20060, 2013.

Oppo, D. W., McManus, J. F., and Cullen, J. L.: Abrupt Climate Events 500,000 to 340,000 Years Ago: Evidence from Subpolar North Atlantic Sediments, Science, 279, 1335-1338, https://doi.org/10.1126/science.279.5355.1335, 1998.

Palumbo, E., Flores, J. A., Perugia, C., Emanuele, D., Petrillo, Z., Rodrigues, T., Voelker, A. H. L., and Amore, F. O.: Abrupt variability of the last 24ka BP recorded by coccolithophore assemblages off the Iberian Margin (core MD03-2699), J. Quat. Sci., 28, 320-328, https://doi.org/10.1002/jqs.2623, 2013.

Peliz, Á., Dubert, J., Santos, A. M. P., Oliveira, P. B. and Le Cann, B.: Winter upper ocean circulation in the Western Iberian Basin Fronts, Eddies and Poleward Flows: an overview, Deep-Sea Res. Pt. I, 52, 621-646, https://doi.org/10.1016/j.dsr.2004.11.005, 2005.

Prahl, F. G. and Wakeham, S. G.: Calibration of unsaturation patterns in long-chain ketone compositions for palaeotemperature assessment, Nature, 330, 367, https://doi.org/10.1038/330367a0, 1987.

Prahl, F. G., Muehlhausen, L. A., and Zahnle, D. L.: Further evaluation of long-chain alkenones as indicators of paleoceanographic conditions, Geochim. Cosmochim. Ac., 52, 2303-2310, https://doi.org/10.1016/0016-7037(88)90132-9, 1988.

Rahman, A.: Reworked nannofossils in the North Atlantic Ocean and subpolar basins: Implications for Heinrich events and ocean circulation, Geology, 23, 487-490, https://doi.org/10.1130/00917613(1995)023<0487:RNITNA>2.3.CO;2, 1995.

Railsback, L. B., Gibbard, P. L., Head, M. J., Voarintsoa, N. R. G., and Toucanne, S.: An optimized scheme of lettered marine isotope substages for the last 1.0 million years, and the climatostratigraphic nature of isotope stages and substages, Quat. Sci. Rev., 111, 94-106, https://doi.org/10.1016/j.quascirev.2015.01.012, 2015.

Relvas, P., Barton, E. D., Dubert, J., Oliveira, P. B., Peliz, Á., da Silva, J. C. B. , and Santos, A. M. P.: Physical oceanography of the western Iberia ecosystem: Latest views and challenges, Prog. Oceanogr., 74, 149-173, https://doi.org/10.1016/j.pocean.2007.04.021, 2007.

Rickaby, R. E. M., Bard, E., Sonzogni, C., Rostek, F., Beaufort, L., Barker, S., Rees, G., and Schrag, D. P.: Coccolith chemistry reveals secular variations in the global ocean carbon cycle?, Earth Planet. Sci. Lett., 253, 83-95, https://doi.org/10.1016/j.epsl.2006.10.016, 2007. 
Ridgwell, A. and Zeebe, R. E.: The role of the global carbonate cycle in the regulation and evolution of the Earth system, Earth Planet. Sci. Lett., 234, 299-315, https://doi.org/10.1016/j.epsl.2005.03.006, 2005.

Rodrigues, T., Voelker, A. H. L., Grimalt, J. O., Abrantes, F., and Naughton, F.: Iberian Margin sea surface temperature during MIS 15 to 9 (580-300 ka): Glacial suborbital variability versus interglacial stability, Paleoceanography, 26, PA1204, https://doi.org/10.1029/2010PA001927, 2011.

Rodrigues, T., Alonso-García, M., Hodell, D. A., Rufino, M., Naughton, F., Grimalt, J. O., Voelker, A. H. L., and Abrantes, F.: A 1-Ma record of sea surface temperature and extreme cooling events in the North Atlantic: A perspective from the Iberian Margin, Quat. Sci. Rev., 172, 118-130, https://doi.org/10.1016/j.quascirev.2017.07.004, 2017.

Rost, B. and Riebesell, U.: Coccolithophores and the biological pump: responses to environmental changes, in: Coccolithophores, Springer Berlin Heidelberg, Berlin, Heidelberg, 99125, 2004.

Rullkötter, J.: Organic Matter: The Driving Force for Early Diagenesis, in Marine Geochemistry, Springer-Verlag, Berlin/Heidelberg, 125-168, 2006.

Ryther, J. H.: Photosynthesis and Fish Production in the Sea, Science, 166, 72-76, 1969.

Saavedra-Pellitero, M., Baumann, K.-H., Ullermann, J., and Lamy, F.: Marine Isotope Stage 11 in the Pacific sector of the Southern Ocean; a coccolithophore perspective, Quat. Sci. Rev., 158, 114, https://doi.org/10.1016/j.quascirev.2016.12.020, 2017.

Salgueiro, E., Voelker, A. H. L., de Abreu, L., Abrantes, F., Meggers, H., and Wefer, G.: Temperature and productivity changes off the western Iberian margin during the last $150 \mathrm{ky}$, Quat. Sci. Rev., 29, 680-695, https://doi.org/10.1016/j.quascirev.2009.11.013, 2010.

Salgueiro, E., Naughton, F., Voelker, A. H. L., de Abreu, L., Alberto, A., Rossignol, L., Duprat, J., Magalhães, V. H., Vaqueiro, S., Turon, J. L., and Abrantes, F.: Past circulation along the western Iberian margin: A time slice vision from the Last Glacial to the Holocene, Quat. Sci. Rev., 106, 316-329, https://doi.org/10.1016/j.quascirev.2014.09.001, 2014.

Sánchez Goñi, M. F., Llave, E., Oliveira, D., Naughton, F., Desprat, S., Ducassou, E., Hodell, D. A., and Hernández-Molina, F. J.: Climate changes in south western Iberia and Mediterranean Outflow variations during two contrasting cycles of the last 1 Myrs: MIS 31-MIS 30 and MIS 12-MIS 11, Global Planet. Change, 136, 18-29, https://doi.org/10.1016/j.gloplacha.2015.11.006, 2016.

Sarmiento, J. L. and Gruber, N.: Ocean Biogeochemical Dynamics, Princeton University Press, USA, New Jersey, 2007.

Sigman, D. M. and Boyle, E. A.: Glacial/interglacial variations in atmospheric carbon dioxide, Nature, 407, 859-869, https://doi.org/10.1038/35038000, 2000.

Silva, A.: Coccolithophores in coastal waters: Lisbon Bay, Portugal, University of Lisbon, 1-220, 2008

Silva, A., Palma, S., Oliveira, P. B., and Moita, M. T.: Composition and interannual variability of phytoplankton in a coastal upwelling region (Lisbon Bay, Portugal), J. Sea Res., 62, 238-249, https://doi.org/10.1016/j.seares.2009.05.001, 2009.

Sousa, F. M. and Bricaud, A.: Satellite-derived phytoplankton pigment structures in the Portuguese up- welling area, J. Geophys. Res.-Oceans, 97, 11343-11356, https://doi.org/10.1029/92JC00786, 1992.

Stein, R., Hefter, J., Grützner, J., Voelker, A., and Naafs, B. D. A.: Variability of surface water characteristics and Heinrich-like events in the Pleistocene midlatitude North Atlantic Ocean: Biomarker and XRD records from IODP Site U1313 (MIS 16-9), Paleoceanography, 24, PA2203, https://doi.org/10.1029/2008PA001639, 2009.

Stoll, H., Shimizu, N., Arevalos, A., Matell, N., Banasiak, A., and Zeren, S.: Insights on coccolith chemistry from a new ion probe method for analysis of individually picked coccoliths, Geochemistry, Geophys. Geosystems, 8, Q06020, https://doi.org/10.1029/2006GC001546, 2007.

Stoll, H. M. and Schrag, D. P.: Coccolith $\mathrm{Sr} / \mathrm{Ca}$ as a new indicator of coccolithophorid calcification and growth rate, Geochemistry, Geophys. Geosystems, 1, 1006, https://doi.org/10.1029/1999GC000015, 2000.

Stoll, H. M. and Ziveri, P.: Separation of monospecific and restricted coccolith assemblages from sediments using differential settling velocity, Mar. Micropaleontol., 46, 209-221, https://doi.org/10.1016/S0377-8398(02)00040-3, 2002.

Stoll, H. M., Klaas, C. M., Probert, I., Encinar, J. R., and Alonso, J. I. G.: Calcification rate and temperature effects on $\mathrm{Sr}$ partitioning in coccoliths of multiple species of coccolithophorids in culture, Global Planet. Change, 34, 153-171, https://doi.org/10.1016/S0921-8181(02)00112-1, 2002a.

Stoll, H. M., Ziveri, P., M., G., Probert, I., and Young, J. R.: Potential and limitations of $\mathrm{Sr} / \mathrm{Ca}$ ratios in coccolith carbonate: new perspectives from cultures and monospecific samples from sediments, P. Roy. Soc. A-Math. Phy. 360, 719-747, https://doi.org/10.1098/rsta.2001.0966, 2002b.

Tangunan, D., Baumann, K.-H., Pätzold, J., Henrich, R., Kucera, M., De Pol-Holz, R., and Groeneveld, J.: Insolation forcing of coccolithophore productivity in the western tropical Indian Ocean over the last two glacial-interglacial cycles, Paleoceanography, 32, 692-709, https://doi.org/10.1002/2017PA003102, 2017.

Tenore, K. R., Alonso-Noval, M., Alvarez-Ossorio, M., Atkinson, L. P., Cabanas, J. M., Cal, R. M., Campos, H. J., Castillejo, F., Chesney, E. J., Gonzalez, N., Hanson, R. B., McClain, C. R., Miranda, A., Roman, M. R., Sanchez, J., Santiago, G., Valdes, L., Varela, M., and Yoder, J.: Fisheries and oceanography off Galicia, NW Spain: Mesoscale spatial and temporal changes in physical processes and resultant patterns of biological productivity, J. Geophys. Res.-Oceans, 100(, 10943-10966, https://doi.org/10.1029/95JC00529, 2018.

Thomson, J., Nixon, S., Summerhays, C. P., Rohling, E. J., Schoenfeld, J., Zahn, R., Grootes, P., Abrantes, F., Gaspar, L., and Vaqueiro, S.: Enhanced productivity on the Iberian margin during glacial/interglacial transitions revealed by barium and diatoms, J. Geol. Soc. London., 157, 667-677, https://doi.org/10.1144/jgs.157.3.667, 2000.

Toucanne, S., Zaragosi, S., Bourillet, J. F., Gibbard, P. L., Eynaud, F., Giraudeau, J., Turon, J. L., Cremer, M., Cortijo, E., Martinez, P., and Rossignol, L.: A 1.2 Ma record of glaciation and fluvial discharge from the West European Atlantic margin, Quat. Sci. Rev., 28, 2974-2981, https://doi.org/10.1016/j.quascirev.2009.08.003, 2009. 
Tyrrell, T. and Merico, A.: Emiliania huxleyi: bloom observations and the conditions that induce them BT - Coccolithophores: From Molecular Processes to Global Impact, edited by: Thierstein, H. R. and Young, J. R., Springer Berlin Heidelberg, Berlin, Heidelberg, 75-97, 2004.

Tyrrell, T. and Young, J. R.: Coccolithophores, in: Encyclopedia of Ocean Sciences, Elsevier, 606-614, 2009.

Tzedakis, P. C., Wolff, E. W., Skinner, L. C., Brovkin, V., Hodell, D. A., McManus, J. F., and Raynaud, D.: Can we predict the duration of an interglacial?, Clim. Past, 8, 1473-1485, https://doi.org/10.5194/cp-8-1473-2012, 2012.

Vázquez Riveiros, N., Waelbroeck, C., Skinner, L., Duplessy, J.-C., McManus, J. F., Kandiano, E. S., and Bauch, H. A.: The "MIS 11 paradox" and ocean circulation: Role of millennial scale events, Earth Planet. Sci. Lett., 371, 258-268, https://doi.org/10.1016/j.epsl.2013.03.036, 2013.

Villanueva, J., Calvo, E., Pelejero, C., Grimalt, J. O., Boelaert, A., and Labeyrie, L.: A latitudinal productivity band in the central North Atlantic over the last 270 kyr: An alkenone perspective, Paleoceanography, 16, 617-626, https://doi.org/10.1029/2000PA000543, 2001.
Vitorino, J., Oliveira, A., Jouanneau, J. M., and Drago, T.: Winter dynamics on the northern Portuguese shelf, Part 1: physical processes, Prog. Oceanogr., 52, 129-153, https://doi.org/10.1016/S0079-6611(02)00003-4, 2002.

Voelker, A. H. L., Rodrigues, T., Billups, K., Oppo, D., McManus, J., Stein, R., Hefter, J., and Grimalt, J. O.: Variations in midlatitude North Atlantic surface water properties during the midBrunhes (MIS 9-14) and their implications for the thermohaline circulation, Clim. Past, 6, 531-552, https://doi.org/10.5194/cp-6531-2010, 2010

Westbroek, P., Brown, C. W., Bleijswijk, J. van, Brownlee, C., Brummer, G. J., Conte, M., Egge, J., Fernández, E., Jordan, R., Knappertsbusch, M., Stefels, J., Veldhuis, M., van der Wal, P., and Young, J.: A model system approach to biological climate forcing, The example of Emiliania huxleyi, Global Planet. Change, 8, 27-46, https://doi.org/10.1016/0921-8181(93)90061R, 1993.

Wright, A. K. and Flower, B. P.: Surface and deep ocean circulation in the subpolar North Atlantic during the mid-Pleistocene revolution, Paleoceanography, 17, 16-20, https://doi.org/10.1029/2002PA000782, 2002. 